\title{
NBS TECHNICAL NOTE 1129
}

\section{U.S. DEPARTMENT OF COMMERCE / National Bureau of Standards}

\section{Use of Infrared Thermography for Industrial Heat Balance Calculations}




\section{NATIONAL BUREAU OF STANDARDS}

The National Bureau of Standards' was established by an act of Congress on March 3, 1901. The Bureau's overall goal is to strengthen and advance the Nation's science and technology and facilitate their effective application for public benefit. To this end, the Bureau conducts research and provides: (1) a basis for the Nation's physical measurement system, (2) scientific and technological services for industry and government, (3) a technical basis for equity in trade, and (4) technical services to promote public safety. The Bureau's technical work is performed by the National Measurement Laboratory, the National Engineering Laboratory, and the Institute for Computer Sciences and Technology.

THE NATIONAL MEASUREMENT LABORATORY provides the national system of physical and chemical and materials measurement; coordinates the system with measurement systems of other nations and furnishes essential services leading to accurate and uniform physical and chemical measurement throughout the Nation's scientitic community, industry, and commerce; conducts materials research leading to improved methods of measurement, standards, and data on the properties of materials needed by industry, commerce, educational institutions, and Government; provides advisory and research services to other Government agencies; develops, produces, and distributes Standard Reference Materials; and provides calibration services. The Laboratory consists of the following centers:

Absolute Physical Quantities ${ }^{2}$ - Radiation Research - Thermodynamics and Molecular Science - Analytical Chemistry - Materials Science.

THE NATIONAL ENGINEERING LABORATORY provides technology and technical services to the public and private sectors to address national needs and to solve national problems; conducts research in engineering and applied science in support of these efforts; builds and maintains competence in the necessary disciplines required to carry out this research and technical service; develops engineering data and measurement capabilities; provides engineering measurement traceability services; develops test methods and proposes engineering standards and code changes; develops and proposes new engineering practices; and develops and improves mechanisms to transfer results of its research to the ultimate user. The Laboratory consists of the following centers:

Applied Mathematics - Electronics and Electrical Engineering ${ }^{2}$ - Mechanical Engineering and Process Technology ${ }^{2}$ - Building Technology - Fire Research Consumer Product Technology - Field Methods.

THE INSTITUTE FOR COMPUTER SCIENCES AND TECHNOLOGY conducts research and provides scientific and technical services to aid Federal agencies in the selection, acquisition, application, and use of computer technology to improve effectiveness and economy in Government operations in accordance with Public Law 89-306 (40 U.S.C. 759), relevant Executive Orders, and other directives; carries out this mission by managing the Federal Information Processing Standards Program, developing Federal ADP standards guidelines, and managing Federal participation in ADP voluntary standardization activities; provides scientific and technological advisory services and assistance to Federal agencies; and provides the technical foundation for computer-related policies of the Federal Government. The Institute consists of the following centers:

Programming Science and Technology - Computer Systems Engineering.

'Headquarters and Laboratories at Gaithersburg, MD, unless otherwise noted; mailing address Washington, DC 20234.

${ }^{2}$ Some divisions within the center are located at Boulder, CO 80303. 


\section{Use of Infrared Thermography for Industrial Heat Balance Calculations}

Kenneth G. Kreider and Thomas P. Sheahen

Center for Continuous Process Technology

National Engineering Laboratory

National Bureau of Standards

Washington, D.C. 20234

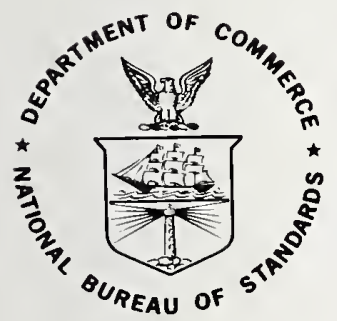

U.S. DEPARTMENT OF COMMERCE, Philip M. Klutznick, Secretary

Luther H. Hodges, Jr., Deputy Secretary

Jordan J. Baruch, Assistant Secretary for Productivity, Technology and Innovation NATIONAL BUREAU OF STANDARDS, Ernest Ambler, Director 
National Bureau of Standards Technical Note 1129

Nat. Bur. Stand. (U.S.), Tech. Note 1129, 38 pages (July 1980)

CODEN: NBTNAE

U.S. GOVERNMENT PRINTING OFFICE

WASHINGTON: 1980

For sale by the Superintendent of Documents, U.S. Government Printing Office, Washington, D.C. 20402

Price $\$ 2.75$

(Add 25 percent for other than U.S. mailing) 
USE OF INFRARED THERMOGRAPHY FOR

INDUSTRIAL HEAT BALANCE CALCULATIONS

Kenneth G. Kreider and Thomas P. Sheahen

\section{$\underline{\text { Abstract }}$}

Infrared thermography has been used to estimate the radiant heat loss from a channel induction furnace containing molten iron. Using this infrared data, the surface temperature was mapped and the convective heat loss was calculated on the basis of a mixed forced and free-convection model. Additional calculations were performed to include the heat conducted away through a water jacket, and the heat lost by infiltration. The furnace energy input was $255 \mathrm{~kW}$, all electrical. The sum of radiation, convection, conduction, and infiltration losses was $246 \mathrm{~kW}$, but the water cooling alone had $\pm 30 \mathrm{~kW}$ associated with it. The radiative and convective losses ( $89 \mathrm{~kW}$ ) were compared with the losses expected on the basis of the original design (107 kW), which is fair agreement. The value of infrared thermography for doing heat balances on industrial furnaces was assessed.

Key Words: Heat balance; industrial furnaces; infrared; thermography. 


\begin{tabular}{|c|c|c|}
\hline A & $=$ & area \\
\hline$a, b, c$ & $=$ & empirical constants \\
\hline B & $=$ & coefficient of thermal expansion \\
\hline $\mathrm{C}$ & $=$ & coefficient of discharge \\
\hline $\mathrm{C}_{\mathrm{p}}$ & $=$ & specific heat of air \\
\hline $\mathrm{D}_{\mathrm{O}}$ & $=$ & furnace diameter \\
\hline$\Delta d$ & $=$ & pressure differential (inches of water) \\
\hline$\varepsilon$ & $=$ & emittance \\
\hline g & $=$ & gravitational constant \\
\hline ho & $=$ & overall coefficient of heat transfer \\
\hline $\mathrm{h}_{\mathrm{c}}$ & $=$ & film coefficient for free convection \\
\hline$h_{f}$ & $=$ & film coefficient for forced convection \\
\hline I & $=$ & intensity of radiation \\
\hline$\Delta \mathrm{I}$ & $=$ & difference in radiation intensity \\
\hline $\mathrm{k}$ & $=$ & thermal conductivity \\
\hline$\dot{\mathrm{m}}$ & $=$ & mass flow rate \\
\hline$\mu$ & $=$ & viscosity of air \\
\hline${ }^{N}$ GR & $=$ & Grashof number \\
\hline $\mathrm{N}_{\mathrm{NU}}$ & $=$ & Nussett number \\
\hline $\mathrm{N}_{\mathrm{PR}}$ & $=$ & Prandt1 number \\
\hline $\mathrm{N}_{\mathrm{RE}}$ & $=$ & Reynolds number \\
\hline $\mathrm{P}$ & $=$ & power \\
\hline$\Delta \mathrm{P}$ & $=$ & pressure differential \\
\hline$\phi$ & $=$ & phase angle \\
\hline$\dot{q}$ & $=$ & heat transfer rate per unit area \\
\hline$\dot{Q}$ & $=$ & heat transfer rate $(\mathrm{kW}$ or $\mathrm{Btu} / \mathrm{hr})$ \\
\hline $\mathrm{r}$ & $=$ & reflectance \\
\hline$\rho$ & $=$ & air density \\
\hline$\sigma$ & $=$ & Stefan-Boltzmann constant \\
\hline $\mathrm{T}$ & $=$ & temperature \\
\hline $\mathrm{T}_{\infty}$ & $=$ & ambient temperature \\
\hline$\Delta \mathrm{T}$ & $=$ & gradient of temperature \\
\hline $\mathrm{U}$ & $=$ & velocity of air \\
\hline $\mathrm{x}$ & $=$ & insulation thickness \\
\hline
\end{tabular}




\section{CONTENTS}

Page

Abstract . . . . . . . . . . . . . . . . . . . . . . . . . . . iii

Nomenclature . . . . . . . . . . . . . . . . . . . . . . . . . . . . . iv

1. Introduction . . . . . . . . . . . . . . . . . . . . . . . . . . . 1

2. Furnace design . . . . . . . . . . . . . . . . . . . . . . . . . 1

3. Infrared thermographic measurements . . . . . . . . . . . . . . . . . . 3

4. Radiant heat loss . . . . . . . . . . . . . . . . . . . . . . 5

A. Temperature map . . . . . . . . . . . . . . . . . . . . . . . . 5

B. Total emitted radiation . . . . . . . . . . . . . . . . . . . . 6

5. Convective heat transfer . . . . . . . . . . . . . . . . . . . 7

A. Free convection . . . . . . . . . . . . . . . . . . . . . . . 7

B. Forced convection . . . . . . . . . . . . . . . . . . . . . . . 8

6. Water cooling . . . . . . . . . . . . . . . . . . . . . . . 9

7. Infiltration losses . . . . . . . . . . . . . . . . . . . . . . 11

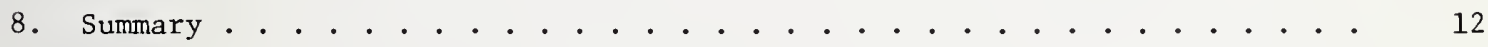

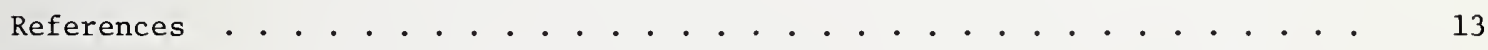

Tables 1 thru 5 . . . . . . . . . . . . . . . . . . . . . . . . . . . . 14

Figures 1 thru 22 . . . . . . . . . . . . . . . . . . . . . . . . . . . 20 

Use of Infrared Thermography for

Industrial Heat Balance Calculations

\section{Introduction}

Infrared thermography is one of the new measurement technologies stemming from the development of good infrared detectors.1 To achieve a two dimensional representation of the surface temperature of an object such as the human body, a house, geographical areas, or industrial equipment the infrared detector is combined with a TV-like scanning camera and the output of the detector is displayed on a cathode ray oscilloscope. The Thermal Processes Division of the National Bureau of Standards is investigating the limits of accuracy and usefulness of infrared thermography when it is used to measure quantitative heat losses from industrial equipment.

Past studies in this area by Hurley and $\mathrm{Kreider}^{2}$ have established the value of infrared thermography as a qualitative tool. These studies have demonstrated the applicability of infrared thermography in saving energy in such diverse industries as cement, paper, forging, foundry, copper, heat treating, refractories, rubber, and heavy manufacturing. The potential for identification of flaws in insulation, malfunctioning electrical components, serious heat losses by infiltration, or any "hot spot" using the infrared thermography has made the infrared survey a powerful tool in energy conservation programs.

The purpose of this study was to find if infrared thermography could be used to quantify the heat losses of an industrial furnace. This quantification is important if management decisions are to be made on investments in improvements such as upgraded maintenance and operating procedures, improved insulation, or redesign of the equipment.

The subject for this study was a channel induction furnace used for holding iron in a molten state prior to pouring castings. This is a particularly desirable target because of it's simplicity: all of the heat input is electrical, and there is no stack or other outlet to carry away a major portion of the heat. Thus, the heat loss mechanisms should be only radiation and convection from the outer surface, and conduction of heat through a water jacket. Had a stack been present (as in furnaces where fossil fuels provide the input energy), it would have been harder to make quantitative measurements.

A common practice in the past has been to perform a heat balance by measuring conduction (water-jacket) losses, estimating stack losses, and then assigning the difference between these and the total input to the broad category "radiation and other". Here we try to minimize the uncertainty by measuring the amount of radiation and calculating that surface loss. In this example, doing so led us to a careful analysis of the remaining discrepancy, and hence to the identification of the chimney effect, leaving our calculation with a value of zero for "other" heat losses.

\section{Furnace Design ${ }^{3}$}

The channel induction is shown schematically in Figure 1; Figures 2 and 3 are photographs of the particular unit we studied. The furnace is basically a large cylinder lying horizontally, with the heating element attached at the bottom. The function of the furnace is simply to hold iron in a liquid state until it is ready to pour into castings. Molten iron is poured into the upper left of the furnace through a tube called the "launder". The iron is held around $1425^{\circ} \mathrm{C}\left(2600^{\circ} \mathrm{F}\right)$, just above its melting temperature.

At the bottom of the furnace hangs an appendage known as the "channe1". Liquid iron is free to circulate through this channel, and an inductor is wound around it. Electrical current flowing through the inductor dissipates energy as heat in the iron, thereby making up for losses through the walls. Since the electrical coil is made of copper, additional cooling is required to keep it far below the temperature of molten iron; this cooling is provided by making the coil out of a hollow copper tube, and running water through it. The water carries away about $120 \mathrm{~kW}$, roughly half of the wattage required to run the furnace. 
Figure 3 shows that the upper right front of the furnace contains a pouring spout, from which liquid iron is poured into castings by rotating the furnace slightly about its principal axis. Figure 2 shows that the rear of the furnace contains two slag doors; just before castings are to be poured, the furnace can be tipped the other way and slag poured off the top of the iron.

The furnace has an outside diameter of $3.1 \mathrm{~m}(10.2 \mathrm{ft})$ and a length of $3.7 \mathrm{~m}(12.2 \mathrm{ft})$. The total surface area is roughly $56 \mathrm{~m}^{2}\left(603 \mathrm{ft}^{2}\right)$. The furnace holds about $50,000 \mathrm{~kg}$ (55 tons) when filled reasonably near capacity, although the total inside volume is $10 \mathrm{~m}$. In the equilibrium or "holding" mode, this furnace is expected to draw $220 \mathrm{KW}$. Since our measurements were made on a day when the power was $255 \mathrm{~kW}$, there is reason to believe that the furnace was operating about $15 \%$ below the rated efficiency.

The furnace wall is $1 / 2$ meter (19 inches) thick, comprising 3 courses of brick and a 3-cm-thick steel she11. There is one more layer of "insulation" that must be included: the boundary layer of air surrounding the furnace, across which the temperature drops from that of the steel shell to ambient conditions. Assuming a planar model, the equation for the heat transfer $\dot{q}$ is ${ }^{4}$

$$
\dot{q}=\frac{\Delta T}{\frac{x_{1}}{k_{1}}+\frac{x_{2}}{k_{2}}+\frac{x_{3}}{k_{3}}+\frac{x_{s}}{k_{s}}+\frac{1}{h_{0}}}
$$

where $\Delta T=T$ (iron) $-T$ (ambient), $k_{i}$ denotes thermal conductivity, $x_{i}$ denotes thickness, the subscripts 1, 2, 3 refer to the 3 layers of brick and s refers to the steel; $h_{0}$ is the overall coefficient of heat-transfer away from the surface.

Knowing the thickness and thermal conductivity of each layer allows us to calculate the heat flow rate $\dot{q}$ through the wall, and the temperature at any point within the wall. The furnace walls have different kinds of insulating bricks above and below the metal level, so an accurate calculation of the heat transfer requires the accumulation of separate contributions from parts of the wa1ls. Moreover, the various apertures (pouring spout, slag doors, etc.) must have their heat loss accounted for as well.

The heat loss rate for this furnace depends primarily on the properties of the insulating brick and is less sensitive to the properties of the other resistance terms. For example, the numerical values pertaining to the heat flow through the cylindrical wa11 are:

$$
\dot{\mathrm{q}}=\frac{2600^{\circ} \mathrm{F}-86^{\circ} \mathrm{F}}{.543+.477+3.478+.004+0.333}=\frac{520 \mathrm{Btu} / \mathrm{hr}}{\mathrm{sq} \mathrm{ft}}=1640 \frac{\mathrm{W}}{\mathrm{m}^{2}}
$$

The denominator contains 0.333 as the estimate for the thermal resistance term from the surface to the surroundings, corresponding to the rough approximation $h_{0}=3$. The coefficient selected for the boundary layer lumps both radiative and convective heat losses together, and this is a valid approximation in this range of temperatures. As temperature rises, radiative losses vary as $\sigma \mathrm{T} 4$, while convective losses vary at $(\Delta \mathrm{T})^{4 / 3}$ over a wide range. Accordingly, we calculake that the radiation component increases by $100 \%$ as the wal1 temperature increases from $95^{\circ}$ to $138^{\circ} \mathrm{C}\left(200^{\circ} \mathrm{F}-280^{\circ} \mathrm{F}\right)$ [assuming a $30^{\circ} \mathrm{C}\left(86^{\circ} \mathrm{F}\right)$ ambient], while the convection component increases by $97 \%$ for the same change. If the estimate of the overall heat-transfer coefficient were doubled or halved it would make only about $6 \%$ difference in the heat flow.

What is actually taking place is that the hot iron drives a certain amount of heat through the insulating bricks and presents it at the outer shell for disposal to the surroundings. If due to obstacles, convection carries away only a little heat, the surface temperature will rise enough to dispose of more of the heat via radiation. If convection is made more important (as when a fan is blowing), the surface temperature drops and a smaller fraction of the total heat is radiated away. 
A similar analysis can be carried out for the heat loss through the end caps of the cylindrical furnace and through the inductor. The several contributions, each with different heat flow rates $\dot{q}$ corresponding to different insulation thicknesses, may then be summed.

The total heat loss according to this design calculation is $107 \mathrm{~kW}$ when the interior iron is in equilibrium 5 at $1425^{\circ} \mathrm{C}\left(2600^{\circ} \mathrm{F}\right)$ and the ambient is $26^{\circ} \mathrm{C}\left(78^{\circ} \mathrm{F}\right)$. This loss is only from convection and radiation by the furnace, and does not include heat carried away by the water jacket surrounding the channel inductor.

The water jacket is a large heat sink for the furnace, typically $120 \mathrm{~kW}$. In the inductor itself, electricity is carried through hollow copper tubes, and water is run through the tubes to keep them cool; typical maximum water temperatures are $65^{\circ} \mathrm{C}\left(150^{\circ} \mathrm{F}\right)$, thus indicating a gradient of some $1360^{\circ} \mathrm{C}\left(2450^{\circ} \mathrm{F}\right)$ across a few inches of insulation. The water cooling includes a loop that runs around the bushing between the throat and the inductor. In addition, another water line cools the launder (the charging tube) whenever it is in place. The flow capacity of the water jacket permits the furnace to draw up to $580 \mathrm{~kW}$ without risk of damage.

The standard operating procedure is to fill the furnace via the launder, then remove the launder and seal its opening. The slag doors should fit securely to minimize air leakage. The pouring spout is normally not plugged, as there must be some escape route for hot gases resulting from the combustion of carbon in the iron. In actual practice, this furnace was generally operated with the launder left in the furnace opening, because of the difficulty of moving it. Also, the slag doors were not always tightly shut. These deviations from the design operating method are commonplace in the iron casting industry.

\section{Infrared Thermographic Measurements}

The channel induction furnace was surveyed on two separate occasions. In the interim, the furnace interior lining and the channel inductor were replaced. Erosion of the insulation in the channel is the most critical factor determining the need to rebuild the furnace.

We used an AGA 680 "Thermovision" system for our measurements ${ }^{6}$. This instrument senses infrared radiation in the 3 to $5.6 \mu \mathrm{m}$ region of the spectrum, a range ideally suited for temperatures typical of furnace walls $\left(100-500^{\circ} \mathrm{C}\right)$. The theory of infrared measurements is covered elsewhere7. The same unit has been used previously to make qualitative measurements of a variety of industrial targets ${ }^{2}$. Here our purpose was to -make quantitative measurements, specifically to determine the surface temperature from measurements of the radiation detected by the thermographic scanner.

Figures 2 - 17 display visible and infrared images of various portions of this furnace. It should be clearly understood that the infrared pictures are not taken by using "infrared film" in a conventional camera. Rather, these are pictures of the screen of a display monitor on which the electronic signal measured by the infrared scanner was projected; they are the equivalent of photographing a television screen.

It is appropriate here to explain how these pictures are used to determine temperatures: Figure 3 shows the front of the furnace, the upper left quadrant of which is very uniform in temperature. Just to the lower right of the F\&E symbol, two small temperature gauges were mounted (with magnets) on the furnace face. One of these guages appear as a black circle in the lower right of Figure 4, which is the Infrared image of the upper left quadrant. These guages provide points of known temperature; hence the radiation from any other point can be compared with the radiation from this point and the temperature of the unknown point is determined by using the instrument calibration curves.

At the bottom of the infrared image is a color scale showing increasing temperatures to the right. Using an electronic marker built into the display console, we could determine the intensity of any given spot with a precision of $\pm 1 \%$ of full scale. Alternately, we could set the marker to a desired intensity position on the calibrated scale and then see on the display screen a contour of all points having that intensity. Using two such markers, it was possible to set one marker so as to match the radiation from the point 
where a thermometer was mounted, and then move the other marker up and down the scale to see contours of all other radiation intensities in the area of interest.

Figure 5 is a photograph showing the upper right quadrant of the front of the furnace, which contains the pouring spout. Here a great deal of heat is being lost from the walls of the spout and from the cylinder wall adjacent to the spout. Although the area is relatively sma11, the temperatures are sufficiently high that these losses comprise a significant fraction of the total radiant heat loss, as shown in Table 1 . There are hot combustion gases escaping from the spout, so the radiation from that region is so intense as to be off-scale in the thermal image of Figure 6. Figure 7 shows the same infrared view, but with the overall intensity reduced by changing the $\mathrm{f} / \mathrm{stop}$ on the thermographic scanner. This brings all regions of the spout except the flame itself down within the range of the scale, thus allowing temperature determinations to be made. of course, the cooler regions of the surface can no longer be so finely resolved in temperature in Figure 7. Therefore, whenever a wide range of temperatures is studied, we use a combination of scanner and display settings to generate a series of pictures akin to Figures 6 and 7 .

The lower left quadrant of the furnace front is shown in Figure 8. The dark bars are simply a railing which is in the foreground of the picture. One interesting feature of Figure 8 is the hot spot at the bottom of the furnace, at a point right below where the launder tube dumps fresh iron into the furnace. On the basis of the mass of molten iron normally present, and considering the thickness of insulation in the cylinder wall, we would not expect to see a significant temperature rise at that point. The infrared display suggests that possibly there are cracks between the insulating bricks, which permit molten iron to come closer to the steel casing then called for in the design. These may have resulted during charging, when the hot molten iron impinges on the empty cylinder. During the rebuild period, visual inspection of the inside lining did not provide any clear evidence of cracks. The hot spot was seen during plant visits both before and after rebuild.

Figure 9 shows the lower right quadrant of the front of the furnace. The bottom of the spout area is visible, as is the throat leading to the inductor coil. Because of the circulating flow of iron, this region has higher erosion than any other. To help minimize the damage due to heat dissipated in the throat area, a water cooling coil is wrapped once around the throat bushing.

The channel inductor coil appears in Figure 10. The arrangement of platform, etc. made this the only view of this section that could be obtained with the thermographic imaging system. Here we found a significant before-and-after difference. Prior to the rebuild, surface temperatures of up to $357^{\circ} \mathrm{C}\left(675^{\circ} \mathrm{F}\right)$ occured on parts of the inductor surface, based on analysis of the radiation intensity of Figure 11 . After renovation, including the installation of a new channel inductor, the hottest temperature was $268^{\circ} \mathrm{C}$ $\left(515^{\circ} \mathrm{F}\right)$, at about the same position 8 . In any case, it is clear that despite its small area, $\left(4.5 \mathrm{~m}^{2}, 48.8 \mathrm{ft}^{2}\right)$, radiation cooling from the inductor must be included in any comprehensive series of measurements.

The back of the furnace is shown thermographically in Figures 12, 13, and 14 . Figure 2 is the corresponding photograph. The cool vertical stripes in Figure 12 are a water jacket not in use and compressed air lines. The slag doors on the left (Figure 13) and right (Figure 14) were not tightly sealed, and appreciable heat leaked out through their ports. In particular, one prominent loss mechanism was that radiation from the liquid iron reached the surface of the doors and was reflected downward to the bottom of the slag port, where it was again reflected out into the room. In Figure 2 the visible glow coming from below the left slag door supports this mechanism. It is noteworthy that while the thermographic data gives only a qualitative measurement of this multiple-reflection heat loss, the size of the opening indicated by it proves to be crucial when calculating the "chimney effect" in section 7 .

Finally, the ends of the cylinder were also measured. Figure 15 is a photograph of the end near the pouring spout, and Figure 16 is the corresponding thermogram. This end contains a "cold charging door" as its hottest surface. The supporting structure for the furnace-rotating mechanism partially obscures the view of the end of the furnace. Moreover, a nearby wall made it impossible to get the thermographic imager into position 
for a head-on view of the end. As a result, the determination of temperature for this surface is heavily dependent upon interpolation of data from other adjacent surfaces in addition to the data derived from Figure 16.

The opposite end, through which the liquid iron enters via a "launder" inserted in the "hot charging door", is shown in Figure 17. Again, the supporting structure obscures the view. The intense glow coming from the ring around the launder indicates the presence of a direct uninsulated pathway into the molten metal. Also, a blast of hot

air could be felt by climbing up on the supporting structure and standing near the launder aperture. Here thermography does not give a numerical measurement of the heat escaping, but it points to a problem area. Then further study leads to a reasonably accurate quantitative calculation of the loss, as will be shown in section 7 .

\section{Radiant Heat Loss}

The data collected by the infrared thermographic imager need to be converted from the units of intensity in which they are displayed to the temperature of the emitting surface. Once the temperature is known at every point, it is a simple calculation to estimate the total radiation loss from the surface.

\section{A. Temperature Map}

The manufacturer of this system (AGA Corp.) provides typical calibration curves to relate their output scale (expressed in "Isotherm Units") to the temperature of the radiating surface. One typical curve is given in Figure 18. These curves are not simply graphs of $\sigma T^{4}$; because of the limited bandpass of the Indium Antimonide (InSb) detector, they represent a more complicated integral over frequency of the Planck function times the detector response. These curves are generally determined empirically at the time of manufacture. Figure 18 shows the empirical curves as solid lines and the theoretical overlap integrals as dashed lines.

We have calibrated our instrument and found that AGA's typical calibration curves are quite close to ours. Therefore, we used these curves to convert the data to temperature maps. The procedure for doing so relies on knowing a reference temperature within the range of sensitivity of the thermographic system. This was normally accomplished by magnetically attaching a thermometer to the surface within the field of view and comparing camera readings at other points to the reference point.

The radiance leaving a surface is composed of emitted and reflected energy. The reflected energy includes components originating from objects elsewhere in the room; fortunately most of these objects are at ambient temperature. Recalling that, for an opaque surface, reflectance $r$ is related to emittance $\varepsilon$ through $\varepsilon+r=1$, our task is to isolate the emitted component of radiation and thence determine the true surface temperature. The camera viewing a location with a known reference temperature $\mathrm{T}_{\mathrm{r}}$ will have a measured signal $\mathrm{I}_{\mathbf{r}}$. When another nearby location of unknown temperature is observed, its measured signal will be $I_{u}$. We denote the difference by $\Delta I_{u r}=I_{u}-I_{r}$. If the two locations are on the same surface with the same apparent surface conditions, it is reasonable to assume their emittances (or reflectances), are the same. Now if we further assume that the radiation reflected from both locations is the same, then the radiance at the location of the unknown temperature is given by

$$
I_{u}=I_{r}+\Delta I_{u r} / \varepsilon
$$

The imaging system contains an arbitrary zero shifting control (known as a "picture black level" knob) which allows the observer to change the displayed signal from both reference and unknown locations by a constant. In order to determine an unknown temperature, this constant must be eliminated. We standardize $I_{r}$ from the calibration curve of Figure 18, (given a measurement of $T_{r}$ ) and then measure $\Delta I_{u r}$ using the Thermovision. We then determine $I_{u}$ using Eq. (2) and finally obtain the unknown temperature $T_{u}$ from the calibration curve using this value of $\mathrm{I}_{\mathrm{u}}$. This procedure is repeated for each point of interest on the surface of the furnace. 
It is a key assumption here that the reflected radiation field is the same at both locations. Clearly this requires judicious selection of the points of study so that the reference and the unknown temperature locations see similar radiation environments.

One area of uncertainty in determining the temperature from a radiation measurement is the question of how well the emittance $\varepsilon$ is known. For this furnace, we use an emittance of $\varepsilon=0.90$, owing to the dusty and mottled appearance of the painted steel shel19. Arguments could be constructed to favor $\varepsilon=.85$ or $\varepsilon=.95$, so our choice of $\varepsilon=0.90$ is a compromise. Incidentally, if there are two different points of known temperature on the surface being observed, both $\mathrm{I}_{\mathbf{u}}$ and $\mathrm{I}_{\mathbf{r}}$ can be obtained from the calibration chart, and

Eq. (2) can be solved instead for the emittance $\varepsilon$.

After calibration of all the thermograms a mosaic was constructed to cover most of the surface of the furnace. Missing pieces were then interpolated and an overall temperature map was reconstructed. Figure 19 is our final temperature map of the front of the furnace. The vast majority of the area is near $93^{\circ} \mathrm{C}\left(200^{\circ} \mathrm{F}\right)$. The channel inductor and the spout display some sharp temperature gradients. Most of the features were discussed in section 3 above. The error bracket on these temperature measurements can generally be taken as $8^{\circ} \mathrm{C}\left(15^{\circ} \mathrm{F}\right)$.

Figure 20 is the temperature map of the back of the furnace. Leakage above and below the slag doors are an important cause of heat loss here. The very cool region $\left(<70^{\circ} \mathrm{C}\right)$ just below each door is a lip protruding from the cylinder which allows the slag to run off and be collected. The lower rear of the furnace was obstructed from view by a platform, thus preventing us from getting a rear view of the channel inductor.

Temperature maps (not shown in this report) were also made of the ends of the furnace. The temperatures determined from these regions have greater uncertainties, due to the many obstruction of the view. While the external surface of these obstructions appear cool to our scanner, the unseen inner surface reflects heat back to the furnace wall; and therefore it reaches some intermediate temperature. We have not analyzed how such conditions affect heat loss, but qualitatively any re-radiation from an obstruction back toward the furnace will reduce heat flow.

\section{B. Total Emitted Radiation}

When the temperature is known everywhere, it is possible to calculate the radiant heat loss from each point, and sum up the contributions. However, there are several points requiring care:

First, the thermographic pictures show a cylinder on its side. To obtain the true area of any surface element, it is necessary to invert the projection that occured when the original data was taken. We do so with the aid of Figure 21 , an equal-area map of a cylinder: each rectangle has the same area $\left(0.09 \mathrm{~m}^{2}\right.$ or $\left.1.0 \mathrm{ft}^{2}\right)$ in this figure. In this way, the less visible areas near the bottom of the furnace are assigned proper weighting in the calculation of emitted radiation. For this particular furnace, the only place this makes any difference is at the warm spot at the bottom left (Figure 8).

Second, the emittance is normally assumed to be the same for the total radiation (over all wavelengths) as it was for the measured radiation (over the detector'bandpass). In our case, the value $\varepsilon=0.90$ was used again. This assumption amounts to calling the furnace a perfect "graybody", ignoring any wavelength-dependence of the surface emittance or reflectance.

Third, the furnace is radiating into surroundings of about $32^{\circ} \mathrm{C}\left(90^{\circ} \mathrm{F}\right)$ and that background radiation must be taken into account. If we consider the room to be isothermal at the ambient temperature $\mathrm{T}_{\infty}$, then the radiative loss per unit area is:

$$
\dot{q}=\varepsilon \sigma\left[\mathrm{T}^{4}-\mathrm{T}_{\infty}^{4}\right]
$$


Again, we require the surface to be convex or planar so that only interchange with the surrounding walls of the building occurs. We have also assumed diffuse scattering, which is reasonable for the rough and dirty surfaces found on the industrial furnace.

With these provisos, the temperature maps generated above in section 4.A were converted to heat-loss maps by straightforward application of Eq. (3) on a point-by-point basis. Table I and Table II are summaries of the contributions from the various surfaces. The total heat loss by radiation was calculated to be approximately $53 \mathrm{~kW}$. The errorbracket estimates of $\pm 8^{\circ} \mathrm{C}$ on each temperature translate into an error-bracket of $\pm 6 \mathrm{~kW}$ on this total. Incidentally, an error of $\pm 1^{\circ} \mathrm{C}$ in ambient temperature contributes only $\pm 0.3 \mathrm{~kW}$ to the uncertainty in the total radiation loss.

\section{Convective Heat Transfer}

The convective heat loss of the channel inductance furnace can also be calculated knowing the surface temperature together with the ambient conditions. The furnace is basically a free standing cylinder with minor perturbations. In order to calculate the heat loss by convection, two parallel approaches were used: free convection; and forced convection over the hot end, combined with free convection for the balance.

\section{A. Free Convection}

The heat transfer by free convection was calculated by summing the heat loss from the various areas of the cylinder at their respective temperatures according to the following relationship:

$$
\dot{Q}=\sum_{i} h_{c} A_{i} \Delta T_{i},
$$

where $A_{i}$ are elements of the area, and $\Delta T_{i}$ is temperature difference of each area from ambient. The film coefficient $h_{c}$ can be found rigorously using the relationship between Nusselt, Grashof and Prandtl numbers for a horizontal cylinder ${ }^{10}$ :

$$
h_{c}=\frac{\mathrm{N}_{\mathrm{NU}^{\mathrm{k}}}}{\mathrm{D}_{\mathrm{o}}},
$$

where

$$
\mathrm{N}_{\mathrm{NU}}=0.13\left[\mathrm{~N}_{\mathrm{GR}} \mathrm{N}_{\mathrm{PR}}\right]^{1 / 3}
$$

for

$$
10^{9}<\mathrm{N}_{\mathrm{GR}} \mathrm{N}_{\mathrm{PR}}<10^{12}
$$

and

$$
\begin{aligned}
& N_{G R} \equiv \frac{D_{0}^{3} \rho^{2} B g(\Delta T)}{\mu^{2}} \\
& N_{P R} \equiv \frac{C_{p} \mu}{k}
\end{aligned}
$$




$\begin{aligned} B & =\text { coefficient of thermal expansion } \approx 1 / \mathrm{T}_{\infty} \\ \mathrm{C}_{\mathrm{P}} & =\text { specific heat of air }=0.24 \mathrm{cal} / \mathrm{g}{ }^{\circ} \mathrm{C} \\ & =0.24 \mathrm{Btu} / 1 \mathrm{bm}{ }^{\circ} \mathrm{F} \\ \mathrm{k} & =\text { thermal conductivity }=.029 \mathrm{watt} / \mathrm{m}^{\circ} \mathrm{C} \\ & =0.0167 \mathrm{Btu} / \mathrm{hr} \mathrm{ft}{ }^{\circ} \mathrm{F} \\ \rho & =\text { air density }=1.048 \mathrm{~kg} / \mathrm{m}^{3}=0.0654 \mathrm{bm} / \mathrm{ft}^{3} \\ \mathrm{~g} & =\text { gravitational constant }=9.8 \mathrm{~m} / \mathrm{s}^{2} \\ & =4.17 \times 10^{8} \mathrm{ft} / \mathrm{hr} \\ \mathrm{D}_{\mathrm{o}} & =\text { furnace diameter }=3.1 \mathrm{~m}=10.2 \mathrm{ft} \\ \mu & =\text { viscosity of air }=2 \times 10^{-5} \mathrm{~kg} / \mathrm{s} \mathrm{m} \\ & 0.0484 \mathrm{~b} / \mathrm{hr} \mathrm{ft}\end{aligned}$

Although the above technique permits a full understanding of the pertinent parameters, it was not used. A simplified method derived from empirical data in McAdamsll was used to calculate $h_{C}$ on horizontal cylinders. For $\mathrm{D} 3 \Delta \mathrm{T}>10^{2}$, the collected coefficients reduce (in English units) to 0.19 , and we find

$$
\mathrm{h}_{\mathrm{c}}=0.19 \Delta \mathrm{T}^{\mathrm{I} / 3} \text {. }
$$

This expression is also correct for vertical plates (such as the furnace end cap) whenever $\mathrm{L}^{3} \Delta \mathrm{T}>10^{3}$, L being the characteristic dimension.

The local temperature for each area was obtained from Figures $19-21$ and used to construct $\Delta \mathrm{T}_{i}$ in each area zone $A_{i}$. Table III enumerates the individual contributions to the summation [Eq. (4)], and summarizes the free convection heat loss. The heat transfer from the cylinder ( $16 \mathrm{~kW}$ ) dominates, with the end plates contributing $9.2 \mathrm{~kW}$ and the inductor-throat combination adding $4.6 \mathrm{~kW}$, bringing the total free-convection heat loss to $29.7 \mathrm{~kW}$.

It is interesting to compare this result with a rough estimate based on treating the entire furnace as if it had one single average temperature, such that $(\Delta \mathrm{T})$ avg $=78^{\circ} \mathrm{C}=$ $140^{\circ} \mathrm{F}$. Then with a total area of $56 \mathrm{~m}^{2}=604 \mathrm{ft}^{2}$, we obtain $\mathrm{h}_{\mathrm{c}}=.99$ and $\mathrm{Q}=24.5 \mathrm{~kW}$. This is about $18 \%$ lower than the result obtained by using the temperature maps.

\section{B. Forced Convection}

The forced convection was driven by a large fan which generated a velocity of about $16 \mathrm{~m} / \mathrm{s}(53 \mathrm{ft} / \mathrm{s})$ at a rectangular opening in the wall near the inductor; the wind speed slowed as the air flowed over the inductor coil and over $20 \%$ of the cylinder. Only the roughest estimate could be made for the average air velocity at the cylinder surface. The forced-convection heat transfer was calculated for the part of the cylinder nearest to the inductor. We used an average air velocity of $7 \mathrm{~m} / \mathrm{s}$ over a $1.3 \mathrm{~m}(4 \mathrm{ft})$ length of the cylinder.

Here the film coefficient is dependent on the properties of the fluid; the equation for forced convection takes the form

$$
\mathrm{N}_{\mathrm{NU}}=\mathrm{F}\left(\mathrm{N}_{\mathrm{RE}}, \mathrm{N}_{\mathrm{PR}}\right) \text {, }
$$

where $\mathrm{N}_{\mathrm{RE}}$ denotes the Reynolds Number, which in turn is proportional to the velocity of air delivered by the fan. For a variety of cylindrical geometries ${ }^{10}$, the equivalent of

Eq. (5) is 


$$
\frac{\mathrm{h}_{\mathrm{f}} \mathrm{D}_{\mathrm{o}}}{\mathrm{k}}=\mathrm{a}\left(\frac{\rho \mathrm{UD}_{\mathrm{o}}}{\mu}\right)^{\mathrm{b}}\left(\frac{\mathrm{C}_{\mathrm{p}} \mu}{\mathrm{k}}\right)^{\mathrm{c}},
$$

where $a, b$ and $c$ are empirical constants, $U$ is the air velocity, and the remaining symbols are as defined after Eq. (5). In the special case of room temperature air incident upon a very large horizontal cylinder, the best fit to empirical data ${ }^{4}$ gives $a=$ $.027, \mathrm{~b}=.8, \mathrm{c}=1 / 3$, and $\left(\mathrm{c}_{\mathrm{p}} \mu / \mathrm{k}\right)=\mathrm{N}_{\mathrm{PR}}=.692$. It follows at once that

$$
h_{f}=.0239 \mathrm{k}(\rho / \mu) \cdot 8 \mathrm{U}^{8} / \mathrm{D}_{\mathrm{o}} \cdot 2
$$

The average temperature of the air film in the region where forced convection occurs is estimated to be $107^{\circ} \mathrm{C}\left(225^{\circ} \mathrm{F}\right)$. Inserting appropriate numerical values, together with our average velocity estimate of $7 \mathrm{~m} / \mathrm{s}(83,000 \mathrm{ft} / \mathrm{hr})$ into $\mathrm{Eq}$. (8), we find

$$
\mathrm{h}_{\mathrm{f}}=2.4 \mathrm{Btu} / \mathrm{ft}^{2} \mathrm{hr}{ }^{\circ} \mathrm{F} \text {. }
$$

Therefore, in the area washed by the fan (at an average speed of $7 \mathrm{~m} / \mathrm{s}$ ), the film coefficient is about twice the coefficient for natural convection $h_{c}$. Since the area is approximately $20 \%$ of the total area, the total heat loss by convection is increased $20 \%$.

If we replaced each pertinent value of $h_{c}$ in Table III with the forced-convection value $h_{f}=2.4$, we could create the appearance of greater precision. However, doing so would conceal the great uncertainty in air velocity at various points washed by the fan. For the inductor/throat assembly, our model suggest an additional $4.5 \mathrm{~kW}$ of heat carried away under forced convection; it is conservative to estimate an additional $1.6 \mathrm{~kW}$ blown away from the cylinder and spout area due to the fan. These increases bring the total convective heat loss to about $36 \mathrm{~kW}$. Our estimate of the overall uncertainty in this figure is $\pm 7 \mathrm{~kW}$.

\section{Water Cooling}

Water cooling is the largest category of heat losses from the furnace. It was disappointing to find that the measurement of these losses was so difficult that a $\pm 30 \mathrm{~kW}$ error bracket had to be placed upon the data. Since the total water heat loss was approximately $120 \mathrm{~kW}$ this range amounted to $\pm 25 \%$, and proved to be the dominant source of uncertainty in the entire heat balance of the furnace.

The rate of flow of water is simple to measure with 3-place accuracy, using a bucket and stopwatch at the drain of each cooling line. Similarly, the temperature of the water at the inlet and drain can be easily measured with a thermometer. The weakness in this procedure is that the temperatures so measured are not necessarily the temperatures of the water before-and-after cooling the furnace: Between the inlet and the furnace is over 10 meters of various hoses and exposed copper pipe that run near the furnace, in front of the fan, and over supporting structures; from the furnace to the final outlet drain a similar system of hoses and pipes exists.

In order to obtain truly accurate temperature measurements, it would have been necessary to attach thermocouples to the cooling lines just as they entered and left the furnace. It was not possible to do this while the furnace was in operation. Accordingly, the temperature measurements are uncertain to the extent that the cooling water was preheated enroute to the furnace or cooled by the fan enroute to the drain. For these flow rates, $.55^{\circ} \mathrm{C}\left(1^{\circ} \mathrm{F}\right)$ temperature error corresponds to $3 \mathrm{~kW}$ in heat transfer. 
As mentioned in section 2 (Furnace Design), the design parameters call for $120 \mathrm{~kW}$ of heat removal by the cooling streams, which include 5 separate lines: The induction coil itself, which is a current-carrying copper tube with water running through it; two cooling lines around the bushing (the junction between furnace and the appended coil); and two cooling lines around the launder (the filling tube entering the top side of the furnace).

On a separate occasion from our thermographic scan, the furnace was running at an input of $470 \mathrm{~kW}$, a very high heating rate near its design limit. Under those circumstances, the water flow rate and temperature data displayed in Table IV were collected. Given the flow rates and the temperatures at the drains, together with an inlet water temperature of $13^{\circ} \mathrm{C}\left(55^{\circ} \mathrm{F}\right)$, it was simple to calculate the total "heat transfer". But the vagaries of water pre-heating and post-cooling discussed above were still present.

The projection from this data of Table IV to the actual conditions occurring during our thermographic scan (255 kW input) is carried out by making use of two formulas supplied by the furnace manufacturer. The electrical losses in the coil are given by

$$
\dot{\mathrm{Q}}=.015 \mathrm{kVA}
$$

in the bushing, the total heat loss is given by

$$
\dot{\mathrm{Q}}=20+.01 \mathrm{kVA} \text {. }
$$

These formulas represent Inductotherm's experience over a group of several furnaces of the same design, and are therefore entirely adequate within the error limits imposed by the uncertainties in water temperatures.

The factor kVA denotes kilovoltamps, which differs from power (P) by a phase factor $\phi$, through the relation

$$
P(k W)=k V A \cos \phi .
$$

The phase factor at the time of the $470 \mathrm{~kW}$ operation was $\cos \phi=.49$, which implies that $\mathrm{kVA}=960 \mathrm{kilovoltamps}$. Therefore electrical losses in the bushing were $9.6 \mathrm{~kW}$ and in the coil they were $14.4 \mathrm{~kW}$. These numbers appear in the column labeled "electrical" in Table IV. By substracting them from the column labeled "heat transfer" we have constructed the column labeled "thermal".

Our estimates of the water cooling load when the furnace was running at $255 \mathrm{~kW}$ (on the occasion when Figures 4 to 13 were obtained) were made by utilizing these split electrical and thermal losses corrected for the changed conditions. Since these measurements were taken just after the furnace was rebuilt, the standard formula was used for the bushing, with $20 \mathrm{~kW}$ thermal loss assigned to it. The phase factor on that day was $\cos \phi=.46$, so at $255 \mathrm{~kW}$ input we obtain $\mathrm{kVA}=554$. This immediately gives electrical heat losses of $5.54 \mathrm{~kW}$ for the bushing and $8.3 \mathrm{~kW}$ for the coil. These are given in the first data column of Table $V$.

There was no rebuilding or other change in the launder, so the earlier figure of $54.6 \mathrm{~kW}$ from Table IV was retained for that thermal loss. The thermal loss from the throat was reduced slightly from the prior determination of $35.6 \mathrm{kN}$ in Table IV: we reasoned that if the thermal loss from the throat diminished upon rebuilding from 21.8 to $20 \mathrm{~kW}$, the thermal loss from the bushing should decline by the same ratio (.917); on that grounds the entry in Table $\mathrm{V}$ for the rebuilt case is $32.7=35.6 \mathrm{x} .917$.

The total heat loss estimate is thus $121 \mathrm{~kW}$ which is very close to the design value of $120 \mathrm{~kW}$ As mentioned above, it carries an uncertainty of $\pm 30 \mathrm{~kW}$. 
Heat losses from furnaces are also generated by air infiltration and exhaust. These losses are driven by the draft due to height differences of various leaks and are sometimes called chimney losses. An estimate of these losses can be made knowing the amount, temperature, and specific heat of the gas escaping the top hole. In the case of the inductance furnace, two critical holes are present which are the principal cause of infiltration losses. The upper hole is an annulus approximately $1.3 \mathrm{~cm}(1 / 2 \mathrm{in})$ across on the outside of a $35 \mathrm{~cm}$ (14 in) diameter pipe (approximately $140 \mathrm{~cm}^{2}=.153 \mathrm{ft} 2$ ); the lower holes at the slag door seals totals $100 \mathrm{~cm}^{2}(.10 \mathrm{ft} 2)$ in area. Since the volume of gas leaving the upper hole at $1425^{\circ} \mathrm{C}\left(2600^{\circ} \mathrm{F}\right)$ is several times as great as the volume entering at room temperature, the upper hole size limits the rate of flow.

The mass flow rate $\dot{m}$ can be approximated using an expression found in Schuhman 12 . This is an analog of Ohm's law in which the flow rate equals the driving force divided by the resistance; the driving force is determined by the gravitational potential energy of the column of hot gas, and the resistance term corresponds to the kinetic energy dissipated as the gas passes through the hole. We have:

$$
\begin{aligned}
\dot{\mathrm{m}} & =2 \mathrm{ACg} \rho \Delta \mathrm{P} ; \text { or } \\
& =10 \cdot 4 \mathrm{ACg} \rho \Delta \mathrm{d} .
\end{aligned}
$$

In this expression, the geometrical hole area $A$ is reduced by a "coefficient of discharge" $\mathrm{C}=0.95 ; \mathrm{g}$ is the gravitational constant, $9.8 \mathrm{~m} / \mathrm{s}^{2}=32.16 \mathrm{ft} / \mathrm{s}^{2} ; \rho$ is the density of air at the high temperature, $0.03 \mathrm{lbs} / \mathrm{ft} 3$; and $\Delta \mathrm{P}$ or $\Delta \mathrm{d}$ represent the pressure differential. When $\Delta \mathrm{P}$ is expressed in $\mathrm{lbs} / \mathrm{in}^{2}$, the numerical coefficient to convert units is 2 ; when $\Delta \mathrm{P}$ is replaced by $\Delta \mathrm{d}$ expressed in inches of water, the numerical coefficient is 10.4. Adhering to metric units would merely change the numerical coefficient, if one were to express furnace draft in units of pascals.

According to the Marks Handbook 10 , the draft differential per foot of column height is 0.0116 when the hot column is $2600^{\circ} \mathrm{F}$ and the ambient column is $80^{\circ} \mathrm{F}$. In that case the pressure differential becomes

$$
\Delta \mathrm{d}=.0116 \times 2.5=.04 \text { (inches water), }
$$

for the 2.5 foot height difference between the furnace openings. Collecting all the numbers and inserting them into Eq. (13b), we find

$$
\begin{aligned}
\dot{\mathrm{m}} & =.153 \times .05 \times 10.4 \times 32.16 \times .04 \times .03 \\
& =.058 \mathrm{lbs} / \mathrm{sec}=.027 \mathrm{~kg} / \mathrm{s} \\
& =2101 \mathrm{bs} / \mathrm{hr}=95.5 \mathrm{~kg} / \mathrm{hr} .
\end{aligned}
$$

The heat flow via infiltration is then immediately calculated using the specific heat of air and the change in temperature.

$$
\begin{aligned}
\mathrm{Q} & =\mathrm{C}_{\mathrm{p}} \dot{\mathrm{m}} \Delta \mathrm{T}=0.24 \times 210 \times 2500 \\
& =126,000 \mathrm{Btu} / \mathrm{hr} \\
& =37 \mathrm{~kW}
\end{aligned}
$$

Although this seems remarkably large, it was later verified when the method of filling the furnace was changed, the launder tube was scrapped, and the launder hole permanently sealed. This caused a sharp drop in the required holding power of the furnace by $30 \mathrm{~kW}$. Considering the precision of our estimates of area, this agreement is remarkable. Therefore, we have designated the value of $\pm 10 \mathrm{~kW}$ as the uncertaintly on our estimate of the infiltration losses. 
Infrared thermography was used to measure the surface temperatures of a channel inductance furnace. This information was used to perform a heat balance on the furnace, which includes calculations of all heat losses as well as the energy input. The results were compared to a theoretical heat balance accompanying the design of the furnace; that heat balance was based on using accepted values for the thermal conductivity of the walls. The design heat balance is comparable to the operational heat balance; however, the design heat balance does not include infiltration losses which result from leaks at different levels in the furnace. The water jacket losses are a separate question: remember that safety is the prime consideration of the design, while determination of actual energy consumption is the object of the operational heat balance.

The purpose of this study was to evaluate the capabilities of using infrared thermography to perform such a heat balance. A secondary purpose was to determine the actual heat balance, and to find problems in design or operation of these furnaces which can be corrected to save energy.

The steps in the heat balance included calculating: (1) radiation heat losses from the surface, (2) convective heat losses, (3) water jacket losses, and (4) infiltration or "chimney" losses. Each component of heat loss was found by combining infrared or other measurements with engineering approximations of parameters which were difficult to measure rigorously. Figure 22 is a bar chart presenting these calculations. They sum to $246 \mathrm{~kW}$. Estimates of the precision of these results, given individually in the text, were summed randomly to give an overall uncertainty of $\pm 33 \mathrm{~kW}$.

We conclude that, using infrared thermography, a surface temperature map of the furnace can be made with sufficient accuracy so that radiative heat losses are not the principal limitation on accuracy of the total heat balance. However, this whole experiment was part of a learning curve on how to obtain the best measurements. We are confident that subsequent studies will profit from the experience.

The other benefits of the thermographic study include the identification of flaws in the heat confinement of the furnace. This can be done on a qualitative basis; it leads to significant improvements in the performance of the furnace, as has been found on previous studies.

\section{Acknowledgement}

We are very grateful to Clay Scarborough for his extensive and thorough analysis of the thermographic data, and for his model of the convection process. 
1. Levinstein, H. and Mudar, J., "Infrared Detectors in Remote Sensing", IEEE Proceedings, Jan. 1975.

2. NBS Technical Note 923, "Applications of Thermography for Energy Conservation in Industry", C.W. Hurley and K.G. Kreider, October 1976.

3. The numerical calculations in this section have been provided by Mr. C. Mason, Vice President of Inductotherm Corporation, Rancocas, New Jersey. The reader should be aware that the National-Bureau of Standards does not endorse one furnace manufacturer over another, and the choice of Inductotherm for this study should not be construed as such.

4. F. Kreith, "Principles of Heat Transfer", Second Edition, International Textbook Co. (Scranton, PA: 1965).

5. Here we assume the charge of molten iron neither absorbs nor gives off heat, but stays at a constant temperature.

6. This does not necessarily constitute an endorsement of this single manufacturer.

7. Handbook of Military Infrared Technology, W. L. Wolfe, ed., pub. by U.S. Government Superintendent of Documents (Washington, D.C.: 1965).

8. This suggests that infrared thermography could be used to give advance warning of when the channel inductor needs to be replaced.

9. Thermophysical Properties of Matter (The TRP Data Series), Vol. 9, Thermal Radiative Properties-Coatings, Y.S. Touloukian, D.P. DeWitt and R.S. Hervicz, Eds., Plenum Pub. Co. (New York: 1972).

10. Standard Handbook for Mechanical Engineers, Seventh Edition, T. Baumeister and L.S. Marks, Eds., McGraw-Hill (New York: 1967).

11. W.H. McAdams, Heat Transmission, McGraw-Hill (New York: 1954 ).

12. Metallurgical Engineering, R. Schuhman, Addison Wesley, (Cambridge, MA: 1952). 


\section{TABLE I}

Radiation Heat Loss for Individual Areas

$$
\dot{\mathrm{Q}}=\sigma \varepsilon \mathrm{A}\left(\mathrm{T}^{4}-\mathrm{T}_{\infty}^{4}\right) \text { where } \sigma=5.6687 \times 10^{-8} \mathrm{~W} / \mathrm{m}^{2} \mathrm{~K}^{4}, \mathrm{~T}_{\infty}=32^{\circ} \mathrm{C}, \varepsilon=.9
$$

Surface

Region

$\mathrm{T}^{\circ} \mathrm{C}$

$$
\begin{gathered}
\left(\mathrm{T}^{4}-\mathrm{T}_{\infty}^{4}\right) \\
\times 10^{-10}
\end{gathered}
$$

Front :

$\begin{array}{cc}\text { Spout } & \text { Area } \\ \text { " } & \text { " } \\ \text { " } & \text { " } \\ \text { " } & \text { " }\end{array}$

$$
\begin{array}{r}
120 \\
147 \\
175 \\
190 \\
275 \\
1500
\end{array}
$$

Inductor Junction

$\begin{array}{cccc}\text { " } & & 183 \\ \text { " } & & \text { " } & 210 \\ \text { Sum } & & & 225 \\ & & & \\ \text { Bottom Hot } & \text { Spot } & 138 \\ \text { " } & \text { " } & \text { " } & 127 \\ \text { " } & \text { " } & \text { " } & 113 \\ \text { Sum } & & & \end{array}$

Remaining Area 93

Tota1 Front

\section{4623 \\ 4. 5820 \\ 5. 2909}

1.9905

1.6967

1. 3563

.9303
$A\left(m^{2}\right)$

1.293

.744

.093

.056

.205

.009
$\dot{Q}$ (watts)

1004

854

150

107

854

4535 \begin{tabular}{rr}
.070 & 124 \\
.023 & 54 \\
.019 & 51 \\
\hline 2.512 & 7733
\end{tabular}

$.205 \quad 208$

$.247 \quad 214$

.307
.759

$\begin{array}{ll}14.869 & 7057\end{array}$

18.14

15424

Back:

A. Visible Area

$\begin{array}{cc}\text { Doors } & 132 \\ \text { " } & 157 \\ \text { " } & 214 \\ \text { " } & 203 \\ \text { " } & 174 \\ \text { " } & 189 \\ \text { " } & 223 \\ \text { " } & 247 \\ \end{array}$

Sum

1.8273

2.5565

4.7647

4. 2730

3. 1306

3.6946

5.1926

6.4529

6.9729

Remaining Visible 93

Tota1 Visible
3.488

1. 284

.037

.279

.149

.093

.102

.112

$\frac{.093}{5.637}$

.9303
3252

1675

90

608

238

175

270

369

$\frac{331}{7008}$

$\frac{7.494}{13.131}$ 
B. Hidden Area (Treat as Front)

Inductor Junction

$\begin{array}{lll}" 1 & " & 147 \\ " & " 1 & 183 \\ " & " & 210 \\ " & " & 225\end{array}$

2.2490

.205

235

3.4623

124

4.5820

.070

.023

54

5.2909

.019

51

Warm Area

120

1.5520

.419

332

Bottom Hot Spot 138

1.9905

.205

208

1.6967

.247

214

1.3563

$\frac{.307}{1.495}$

$\frac{212}{1430}$

Sum

113

Remaining Hidden Area

\section{3}

.9303

$\frac{3.728}{5.223}$

1769

Total Hidden

18.35

3199

Total Back

13764

Charging End:

Launder Ring 300

9.9242

4.1447

9.9242

.555

2810

Doo

300

Remaining Area 100

1.0717

.888

1878

.222

1124

Sum

$\frac{5.886}{7.55}$

$\frac{3218}{9030}$

Wal1 End:

$\begin{array}{lr}\text { Door } & 252 \\ \quad " & 235 \\ \text { " } & 210 \\ \text { Door Frame } & 182 \\ \text { Structure } & 136 \\ \text { Remaining Area } & 77 \\ \text { Sum } & \end{array}$

6.7385

5.8005

4.5820

3.4056

1.9353

.6304

Inductor:

Rim 120

Front Face 268

1.5520

7.7086

6.6233

5.5419

" " 230

" " 206

4.4038

3.1665

Side of Coils 230

5. 5419

4.4038

$\begin{array}{ll}206 & 4.4038 \\ 175 & 3.1665\end{array}$

Remaining Area 175

Sum

Grand Total of Furnace

.04

.14

.37

.37

3.77

$\frac{2.86}{7.55}$

.484

.093

.047

.047

.047

1.126

.186

.205

$\frac{2.306}{4.54}$

$56.13 \mathrm{~m}^{2}$
137

414

865

643

3722

$\frac{920}{6701}$

383

366

157

132

104

1819

526

461

$\frac{3726}{7674}$

52593 


$\begin{array}{lcc}\text { Location } & \text { Area }\left(\mathrm{ft}^{2}\right) & \dot{Q}(\mathrm{Btu} / \mathrm{hr}) \\ \begin{array}{l}\text { Front: } \\ \text { Spout Area }\end{array} & 27.0 & 26,385 \\ \text { Bottom Hot Spot } & 8.2 & 2,163 \\ \quad \text { Remaining Area } & 159.8 & 24,078 \\ \text { Back: } & 141.2 & 36,048 \\ \text { A. Visible } & 56.2 & 10,915 \\ \text { B. Hidden } & 81.1 & 30,810 \\ \text { Charging End: } & 81.1 & 22,864 \\ \text { Wa11 End: } & 48.8 & 26,184 \\ \text { Inductor: } & 603.4 & 179,447 \\ \text { Grand Total } & \end{array}$


TABLE III

Free Convection Heat Losses

$$
\begin{gathered}
\dot{\mathrm{Q}}=\mathrm{h}_{\mathrm{c}} \mathrm{A} \Delta \mathrm{T} \\
\Delta \mathrm{T}=\mathrm{T}-\mathrm{T}_{\infty} \text { and } \mathrm{T}_{\infty}=32^{\circ} \mathrm{C} \\
\mathrm{h}_{\mathrm{c}}=0.19(\Delta \mathrm{T})^{1 / 3}
\end{gathered}
$$

\begin{tabular}{|c|c|c|c|c|c|}
\hline $\mathrm{T}\left({ }^{\circ} \mathrm{C}\right)$ & $\Delta \mathrm{T}\left({ }^{\circ} \mathrm{C}\right)$ & $\Delta \mathrm{T}\left({ }^{\circ} \mathrm{F}\right)$ & $h_{c}$ & Area $\left(f t^{2}\right)$ & $(B t u / h r)$ \\
\hline 93 & 61 & 110 & .91 & 280.5 & 28027 \\
\hline 113 & 81 & 146 & 1.00 & 6.6 & 962 \\
\hline 120 & 88 & 158 & 1.03 & 18.4 & 2996 \\
\hline 127 & 95 & 171 & 1.05 & 5.3 & 952 \\
\hline 132 & 100 & 180 & 1.07 & 37.5 & 7241 \\
\hline 138 & 106 & 191 & 1.09 & 4.4 & 915 \\
\hline 147 & 115 & 207 & 1.12 & 10.2 & 2365 \\
\hline 157 & 125 & 225 & 1.16 & 13.8 & 3588 \\
\hline 175 & 143 & 257 & 1.21 & 2.6 & 809 \\
\hline 183 & 151 & 272 & 1.23 & 1.5 & 502 \\
\hline 190 & 158 & 284 & 1.25 & 1.6 & 569 \\
\hline 203 & 171 & 308 & 1.28 & 3.0 & 1185 \\
\hline 210 & 178 & 320 & 1.30 & 0.5 & 208 \\
\hline 214 & 182 & 328 & 1.31 & 0.4 & 172 \\
\hline 225 & 193 & 347 & 1.34 & 1.5 & 698 \\
\hline 250 & 218 & 392 & 1.39 & 2.2 & 1200 \\
\hline 275 & 243 & 437 & 1.44 & 2.2 & 1386 \\
\hline \multirow[t]{2}{*}{1500} & 1468 & 2642 & 2.63 & 0.1 & 694 \\
\hline & & & & 392.3 & 54469 \\
\hline
\end{tabular}

Cylinder: 
Charging End:

$\begin{array}{rrrrrr}100 & 68 & 122 & .94 & 63.3 & 7309 \\ 200 & 168 & 302 & 1.28 & 9.5 & 3664 \\ 300 & 268 & 482 & 1.49 & \frac{8.4}{81.2} & \frac{6038}{17011}\end{array}$

Wall End:

$\begin{array}{rrrrrr}77 & 45 & 81 & .82 & 30.7 & 2044 \\ 136 & 104 & 187 & 1.09 & 40.5 & 8240 \\ 182 & 150 & 270 & 1.23 & 4.0 & 1326 \\ 210 & 178 & 320 & 1.30 & 4.0 & 1666 \\ 235 & 203 & 365 & 1.36 & 1.5 & 745 \\ 252 & 220 & 396 & 1.40 & \frac{0.4}{81.1} & \frac{221}{14242}\end{array}$

Inductor:

$\begin{array}{rrrrrr}210 & 88 & 158 & 1.03 & 5.2 & 847 \\ 175 & 143 & 257 & 1.21 & 36.9 & 11480 \\ 206 & 174 & 313 & 1.29 & 2.7 & 1091 \\ 230 & 198 & 356 & 1.35 & 2.5 & 1200 \\ 250 & 218 & 392 & 1.39 & 0.5 & 273 \\ 268 & 236 & 425 & 1.43 & \frac{1.0}{48.8} & \frac{868}{15759}\end{array}$

Total Convection

$$
\begin{aligned}
54469+17011+14242+15759 & =101481 \mathrm{Btu} / \mathrm{hr} \\
& =29.74 \mathrm{~kW}
\end{aligned}
$$


TABLE IV

Cooling Water Measurements

Furnace running at $470 \mathrm{~kW}, \mathrm{~T}$ (input) $=55^{\circ} \mathrm{F} *$

\begin{tabular}{|c|c|c|c|c|c|c|}
\hline Place & Gallons/Min & Tout $\left({ }^{\circ} \mathrm{F}\right)$ & $\Delta \mathrm{T}$ & $\begin{array}{l}\text { Heat Transfer } \\
(\mathrm{kW})\end{array}$ & Elec.+ & Therma 1 \\
\hline Coil \& throat & $33 / 8$ & 156 & 101 & 50.0 & 14.4 & 35.6 \\
\hline Bushing 非 1 & $55 / 8$ & 74 & 19 & $15.67)$ & \multirow{2}{*}{9.6} & \multirow{2}{*}{21.8} \\
\hline Bushing 非2 & $51 / 8$ & 76 & 21 & $15.77)$ & & \\
\hline Launder \#1 & $33 / 8$ & 108 & 53 & $26.2)$ & \multirow[b]{2}{*}{$\begin{array}{r}0 \\
- \\
\end{array}$} & \multirow[b]{2}{*}{54.6} \\
\hline Launder 非2 & $44 / 8$ & 98 & 43 & 28.4 & & \\
\hline Total & & & & 136.0 & 24.0 & 112.0 \\
\hline
\end{tabular}

Conversion factors: 1 gal/minute $=500.41 \mathrm{bs} / \mathrm{hour}$

$$
3412 \mathrm{Btu} / \mathrm{hr}=1 \mathrm{~kW}
$$

*For these flow rates, $1^{\circ} \mathrm{F}$ makes $3 \mathrm{~kW}$ difference.

+The "Electrical" column was generated using Eqs. (10) - (12)

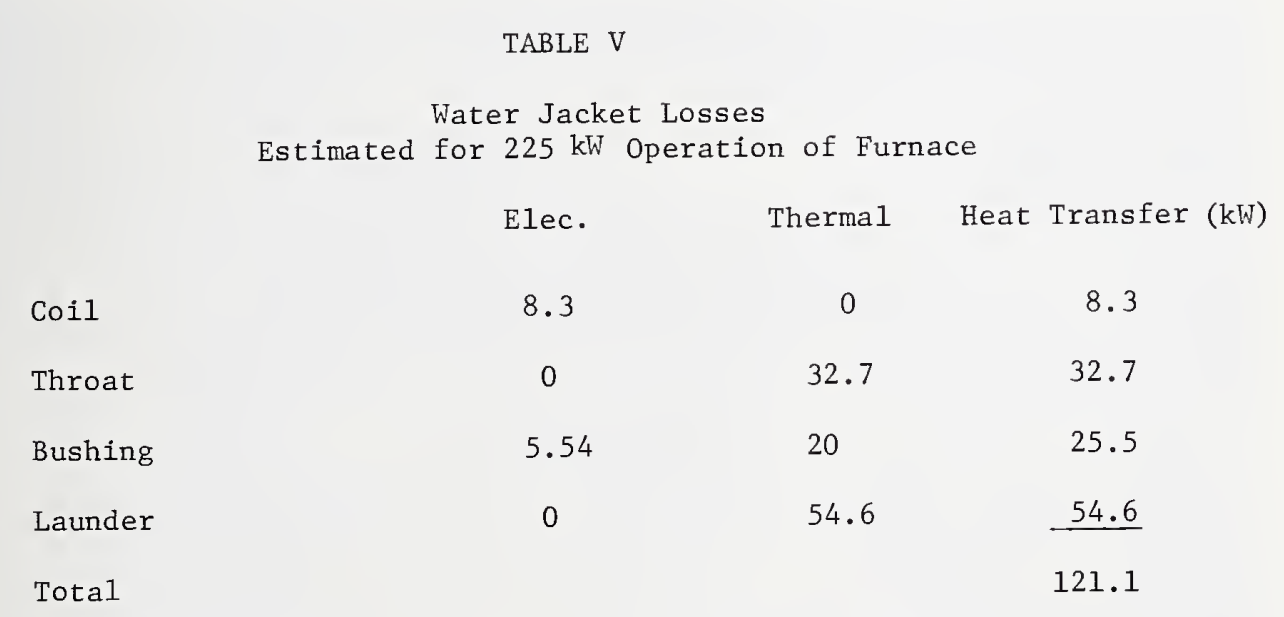




\section{CHANNEL INDUCTION FURNACE}
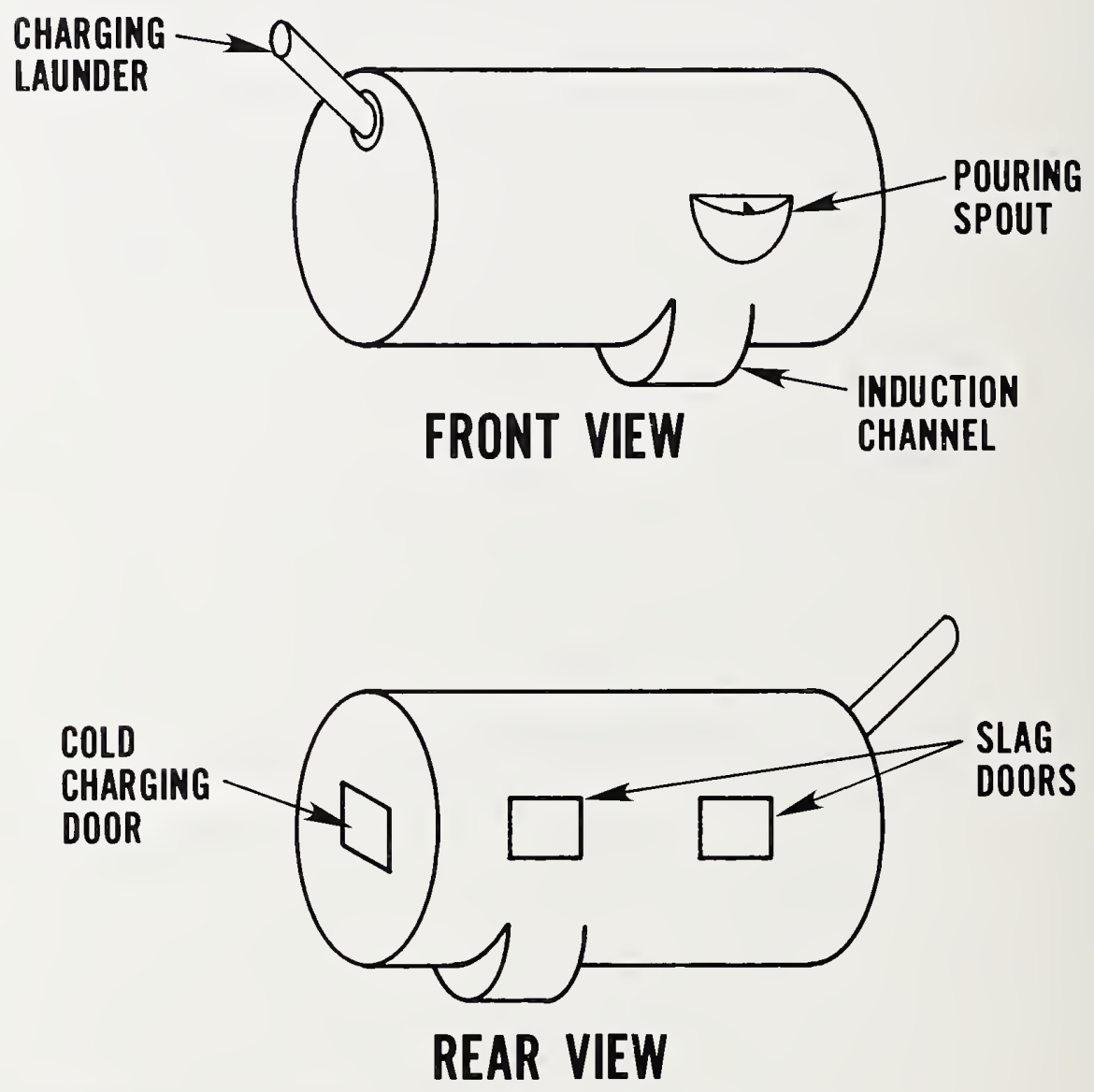

Figure 1. Sketch of Channel Induction Furnace 


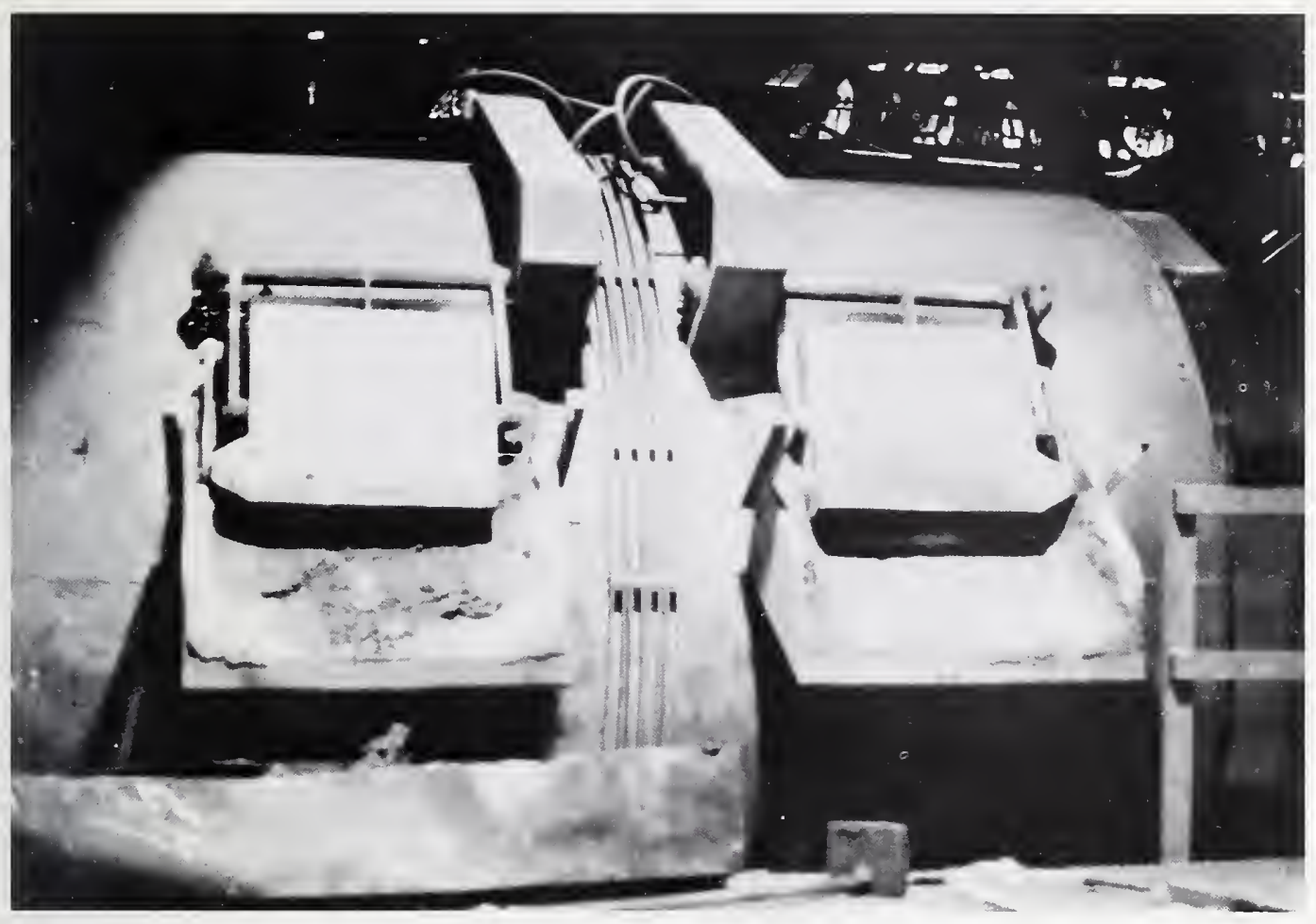

Figure 2. Photograph of Back of Furnace

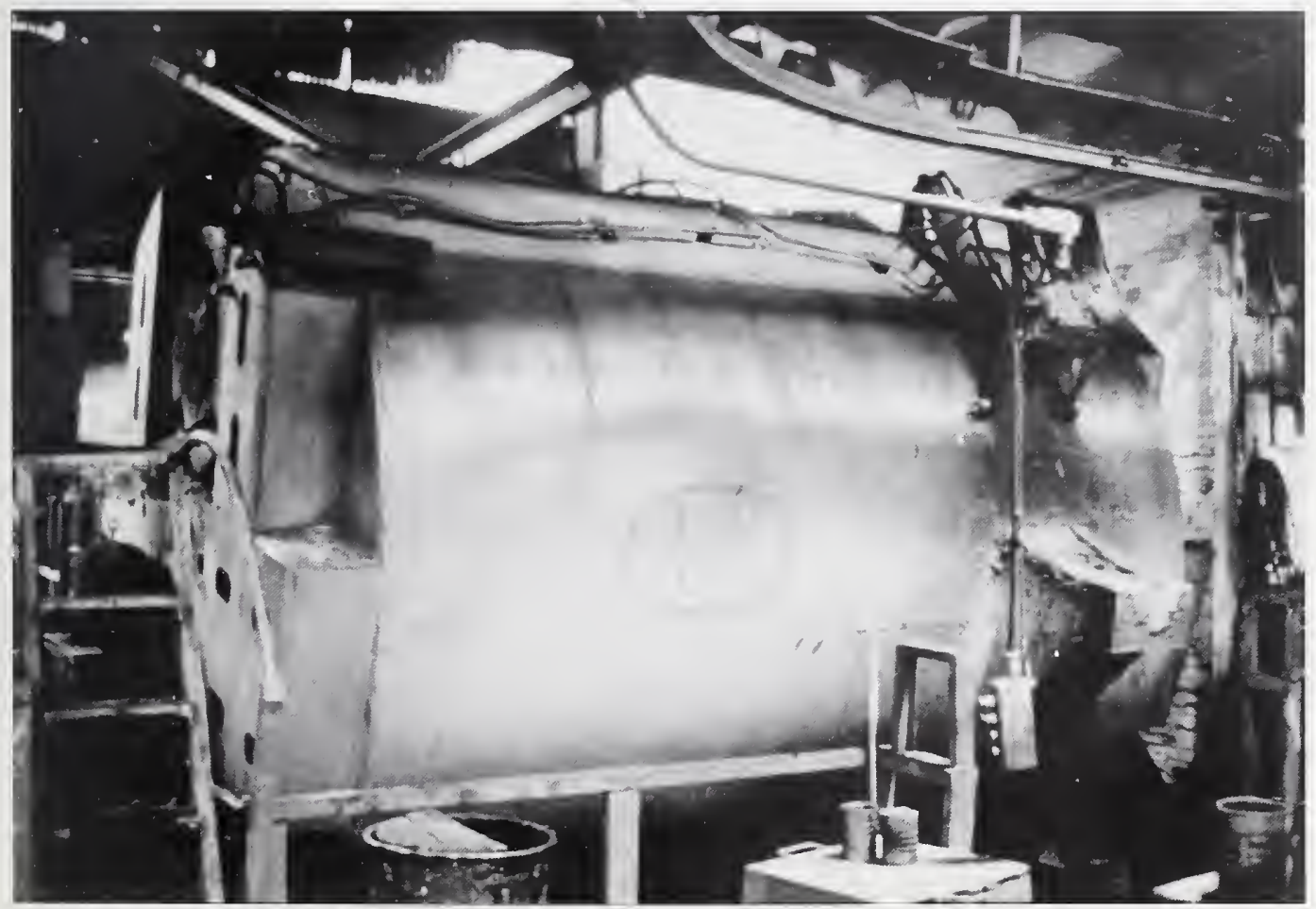

Figure 3. Photograph of Front of Furnace 


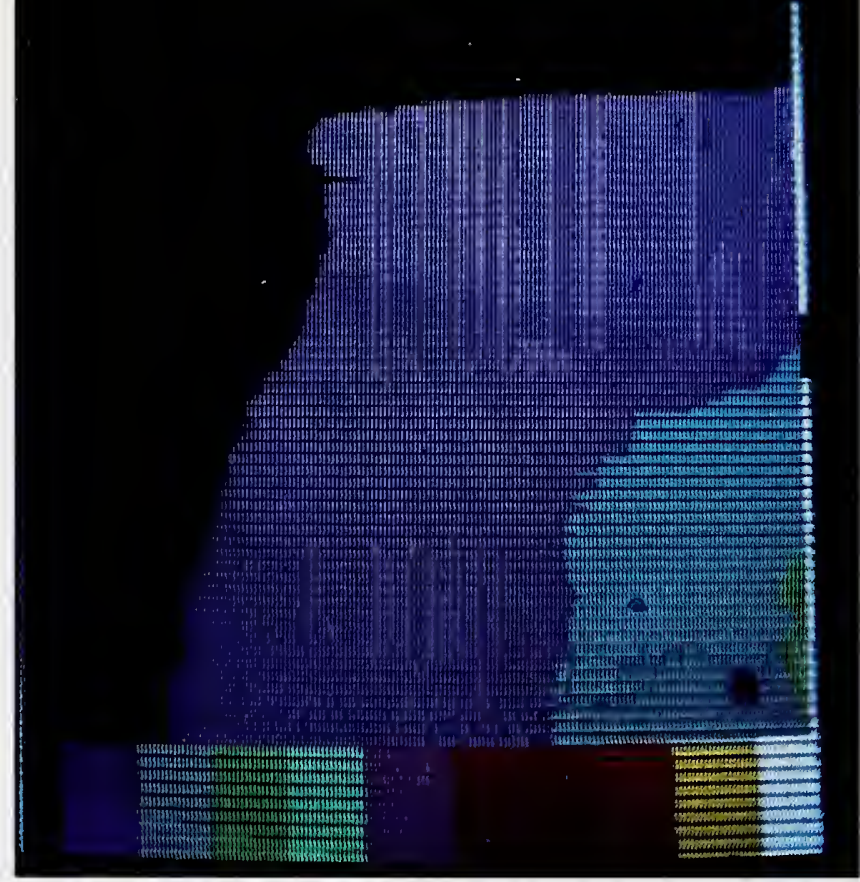

Figure 4. Thermogram of Upper Left Quadrant of Furnace Front

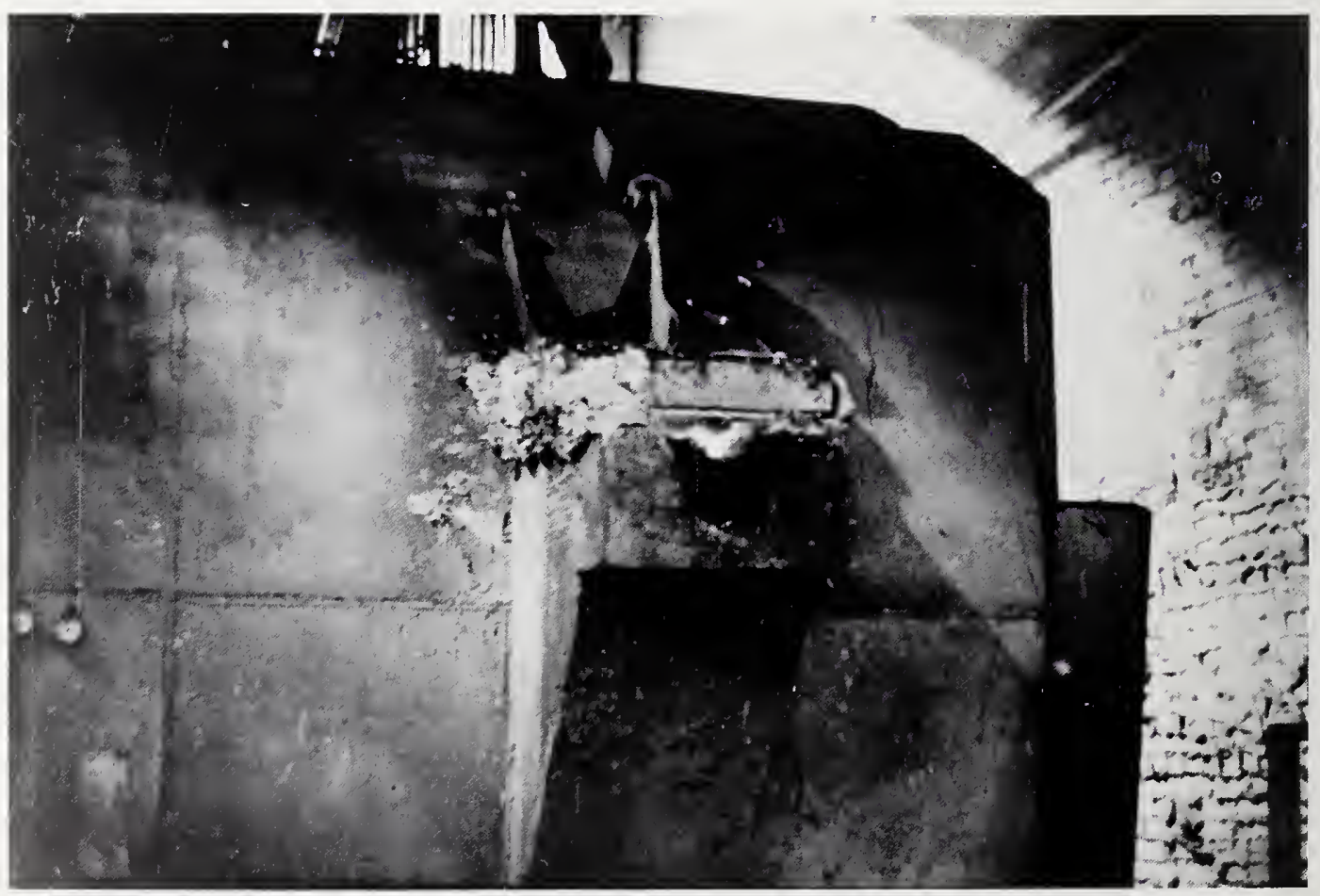

Figure 5. Photograph of Upper Right Quadrant of Furnace Front. 


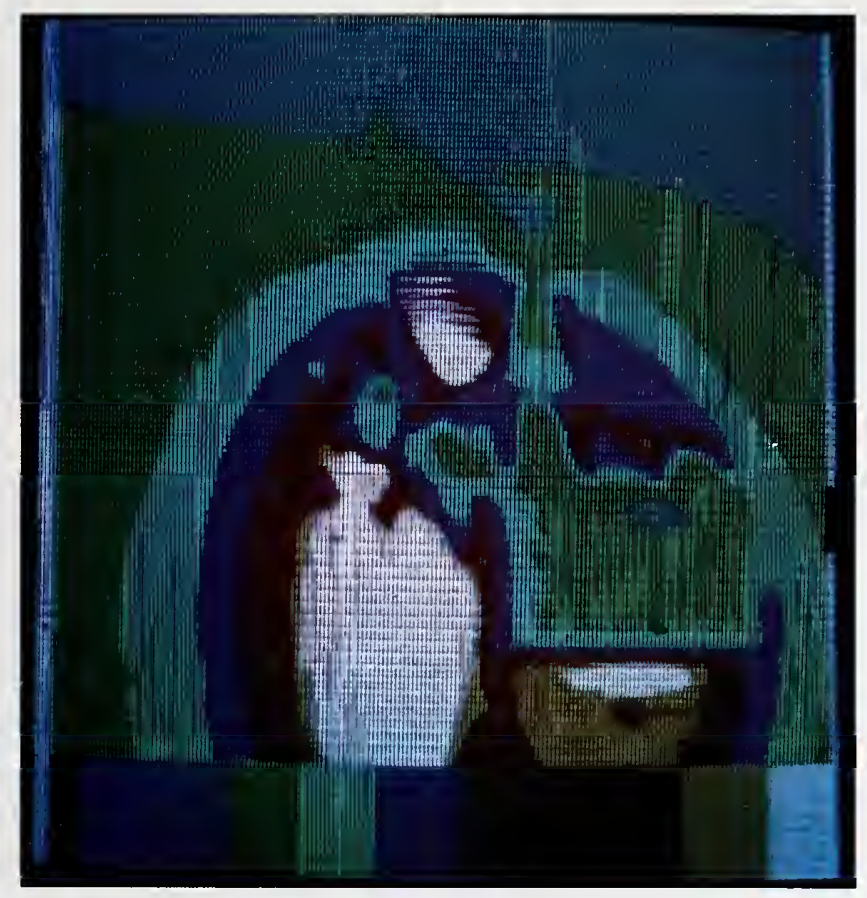

Figure 6. Thermogram of Upper Right Quadrant Using Camera Settings of $\mathrm{f} / 3.6$ and sensitivity $=500$.

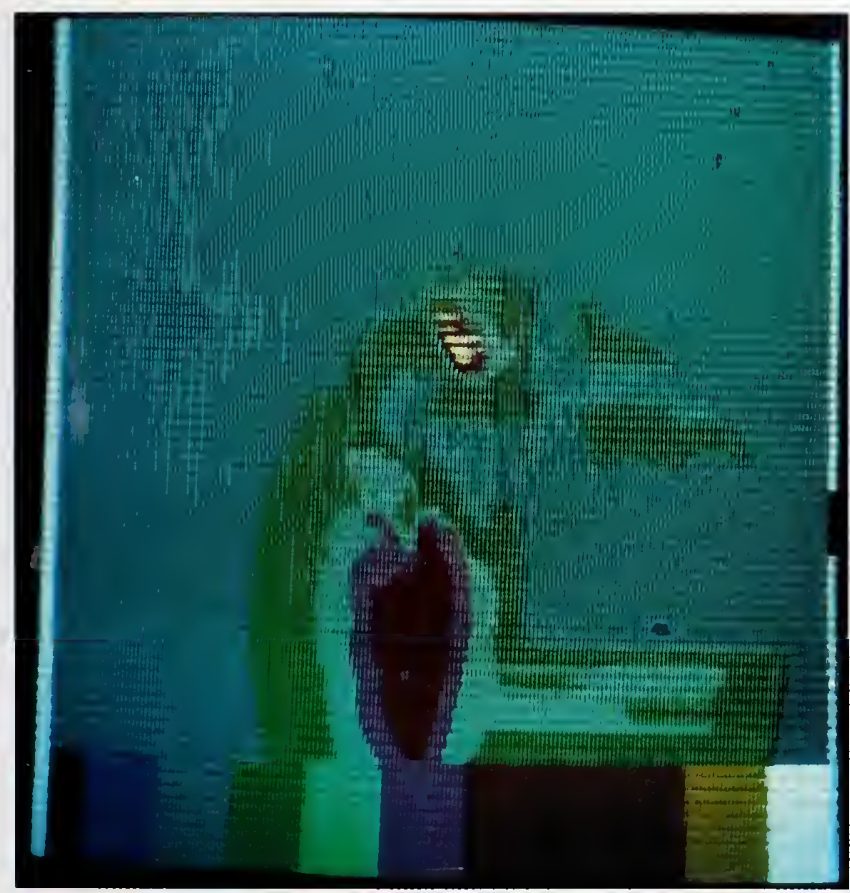

Figure 7. Thermogram of Upper Right Quadrant Using Camera Settings of $\mathrm{f} / 7.2$ and sensitivity $=500$. 


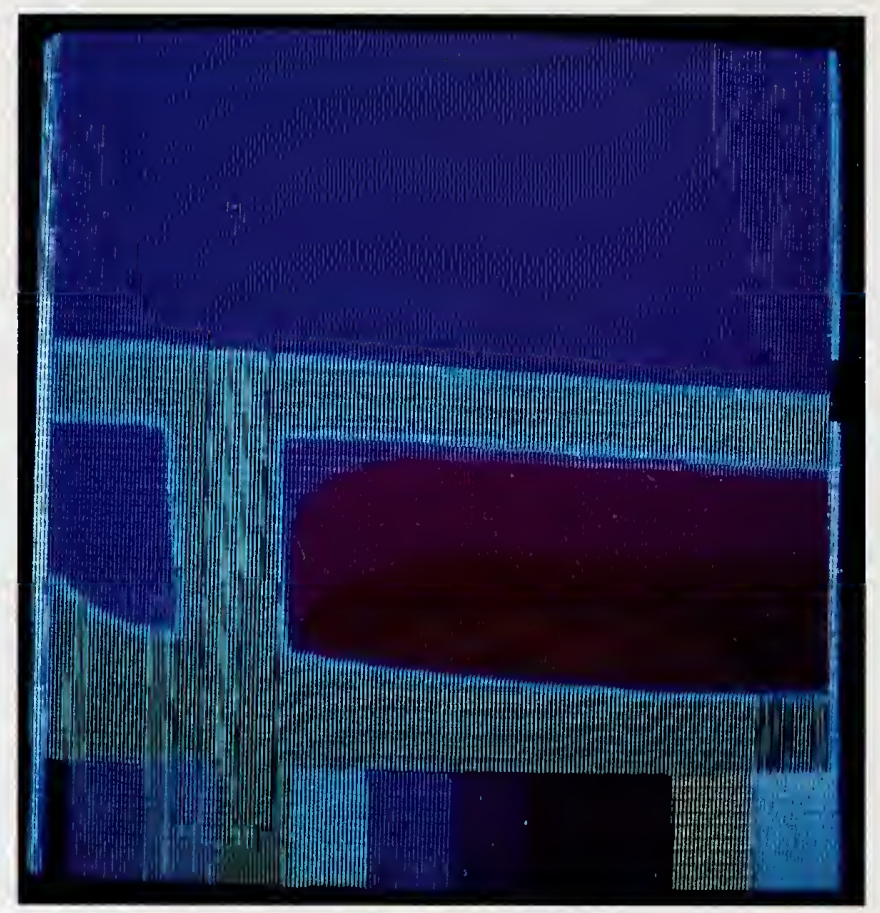

Figure 8. Thermogram of Lower Left Quadrant of Furnace Front. The view is partially obstructed by a railing, but there is a "hot spot" visible at the furnace bottom.

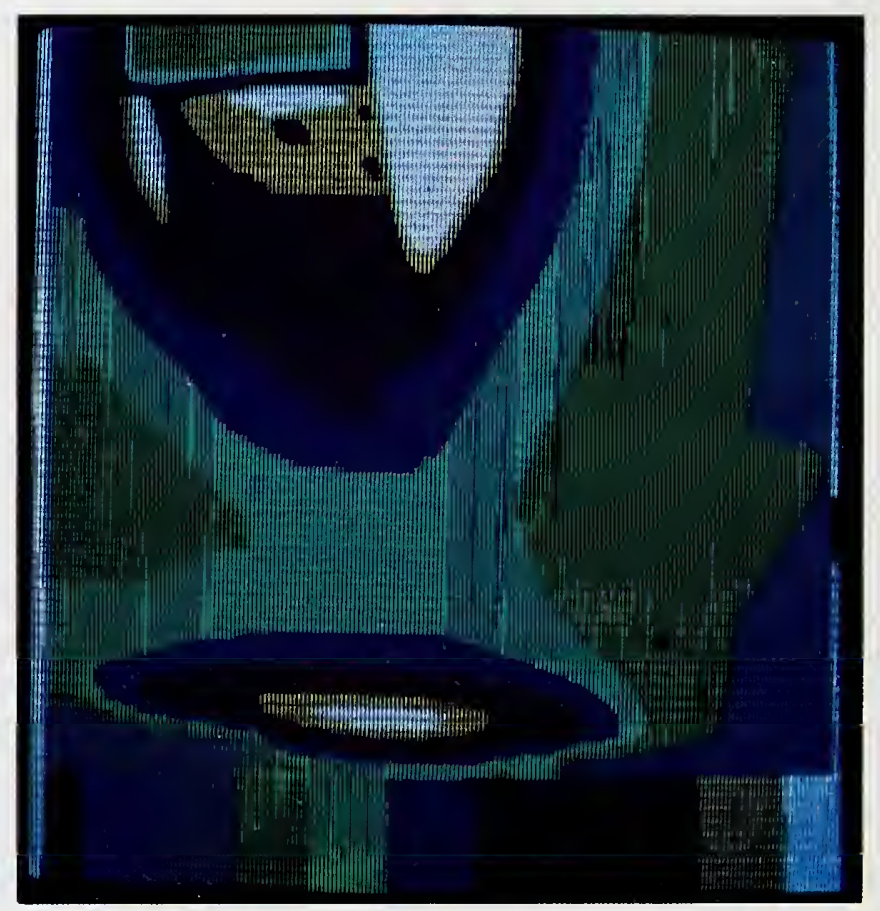

Figure 9. Thermogram of Lower Right Quadrant of Furnace Front. 


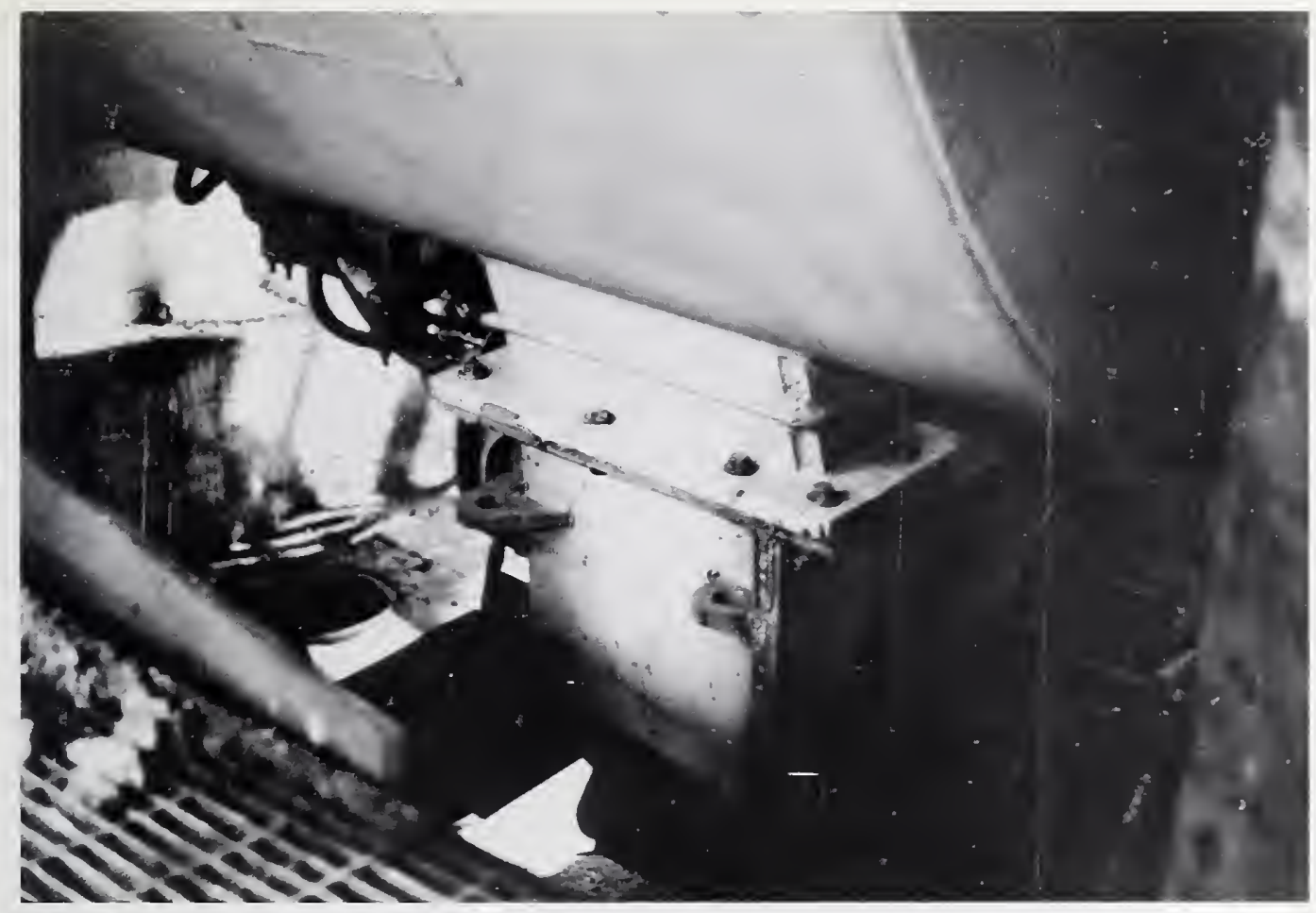

Figure 10. Photograph of Inductor and Throat Appendage to Furnace.

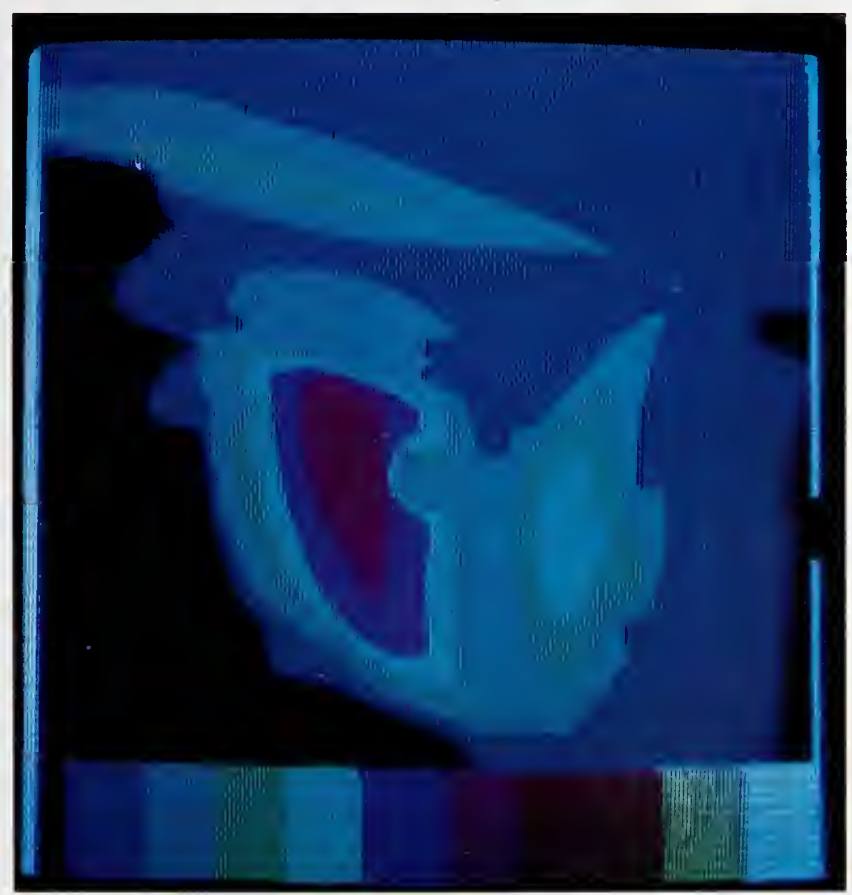

Figure 11. Thermogram of Inductor and Throat 


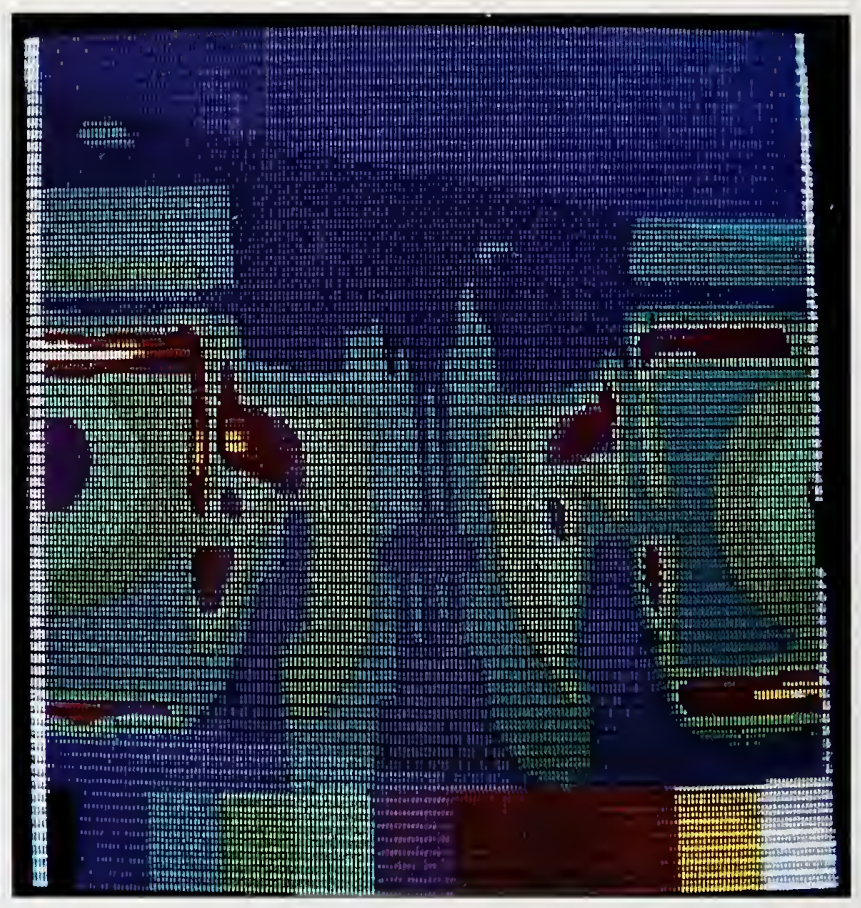

Figure 12. Thermogram of Center of Furnace Back.

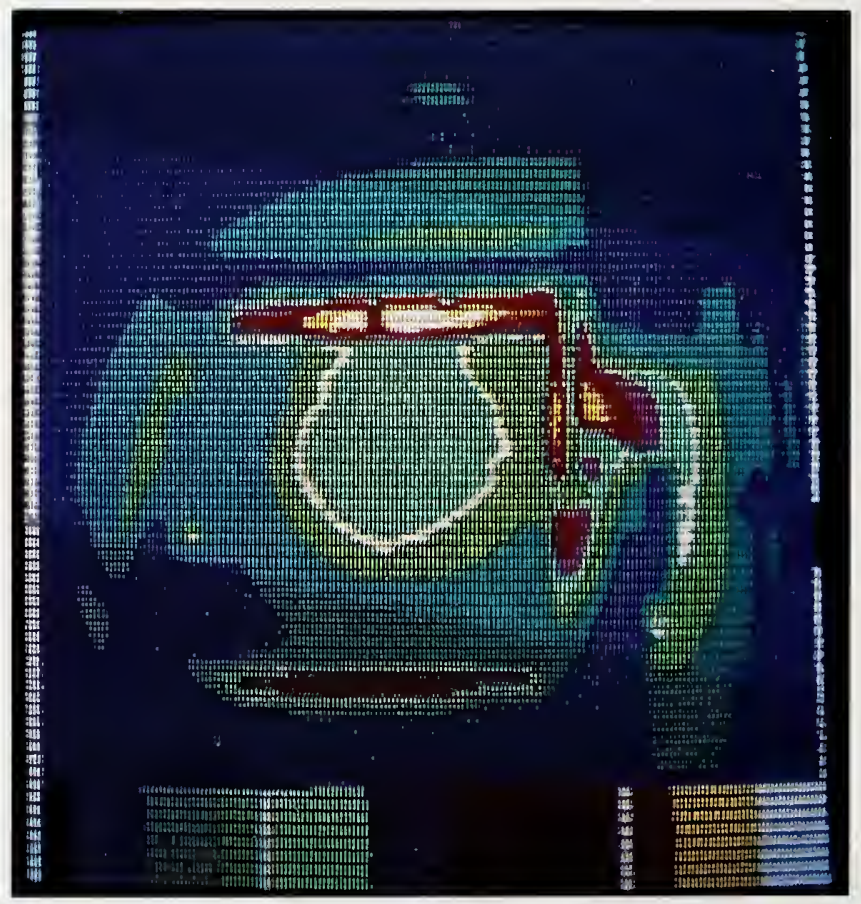

Figure 13. Thermogram of Left Side of Furnace Back. The "isotherm" bars are in use here. 


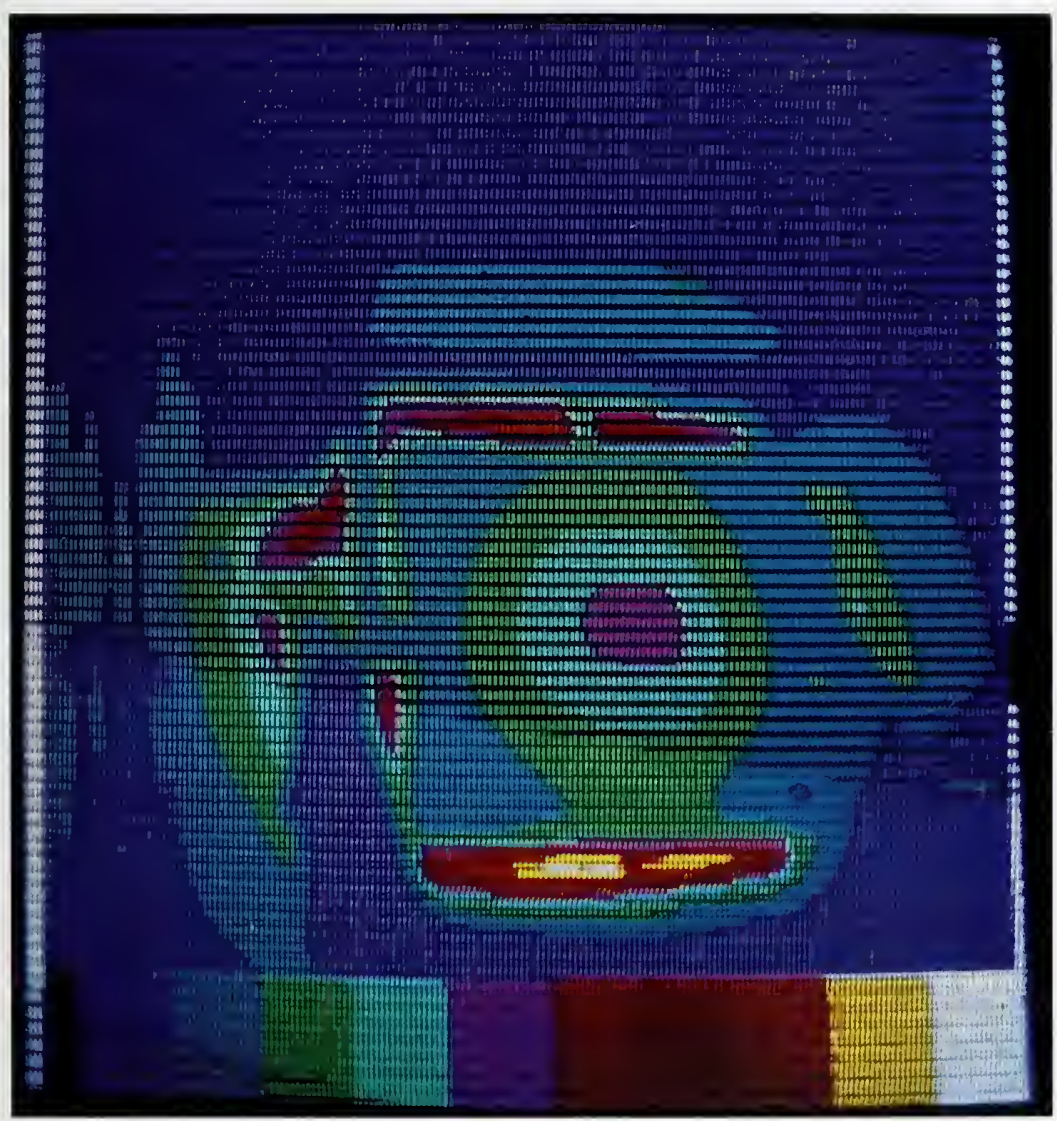

Figure 14. Thermogram of Right Side of Furnace Back 


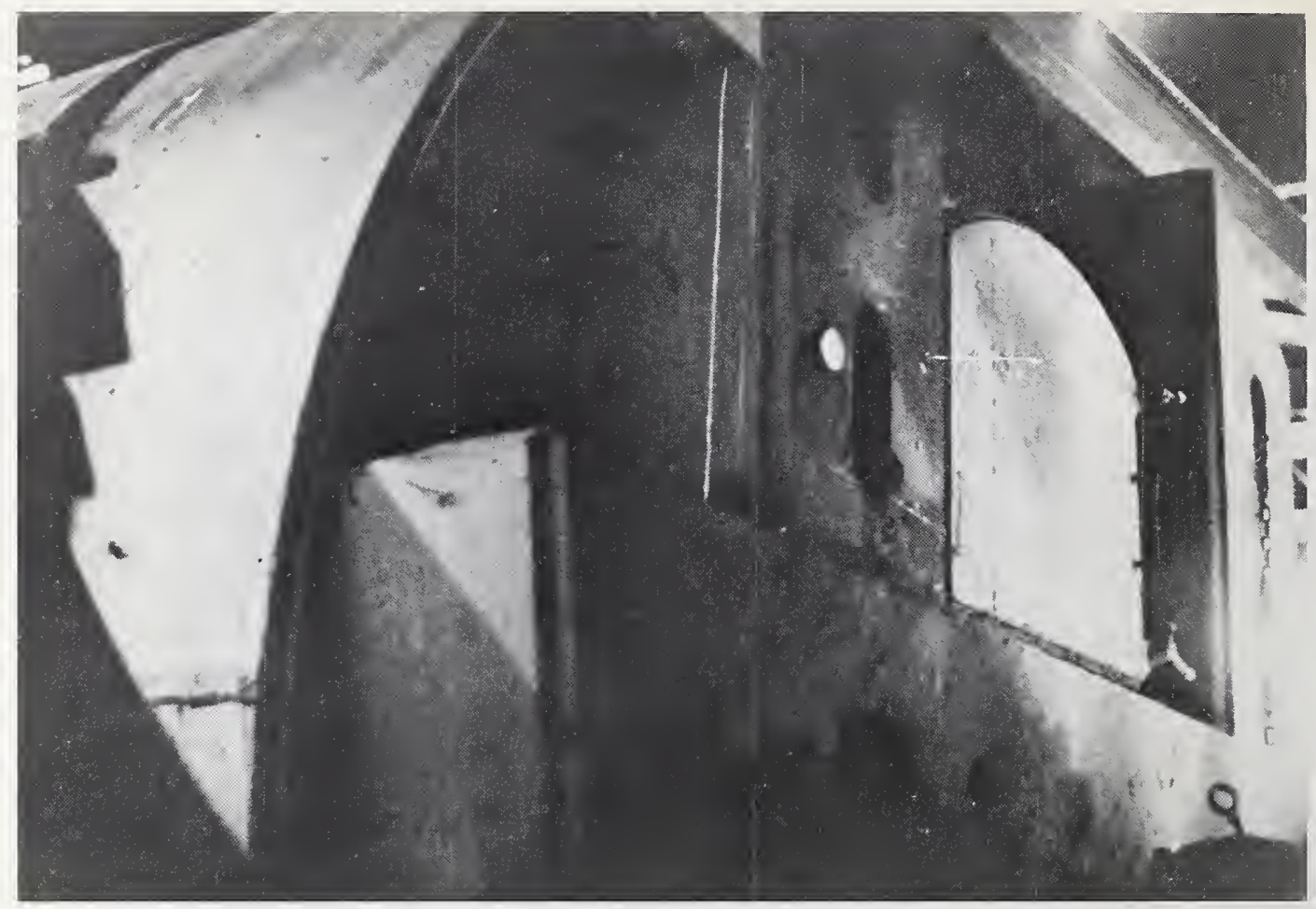

Figure 15. Photograph of side of furnace nearest the pouring spout. A building wall prevented positioning the camera to get a head-on-view of this surface.

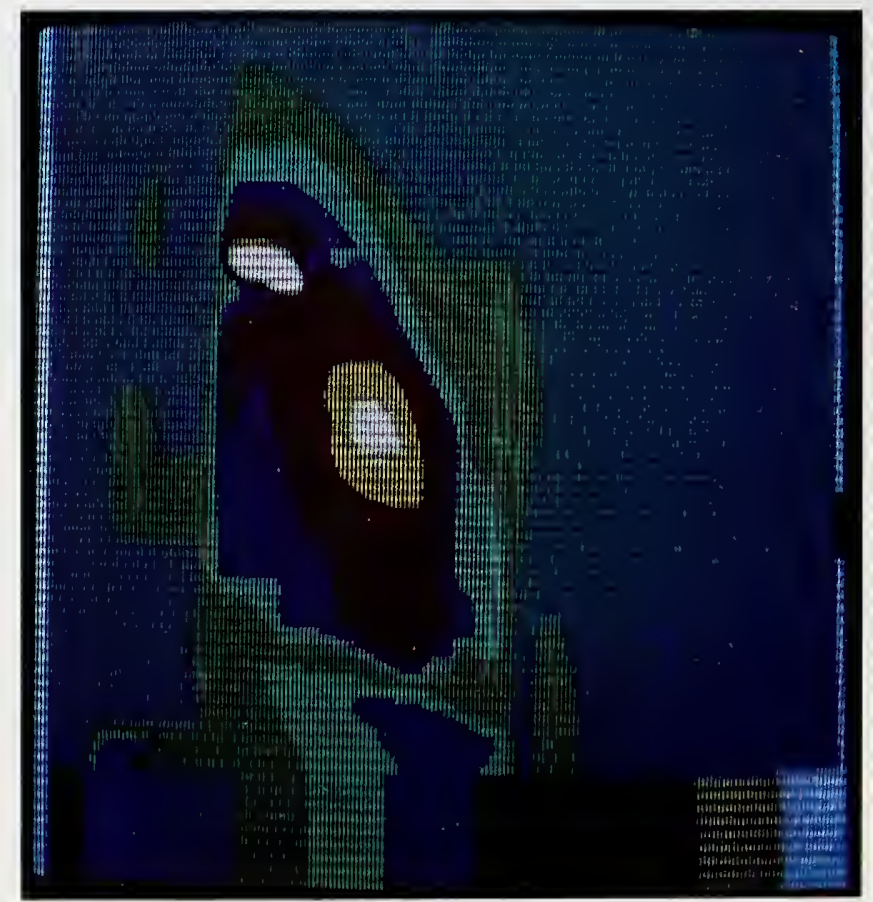

Figure 16. Thermogram of "wall side" shown in Figure 15. 


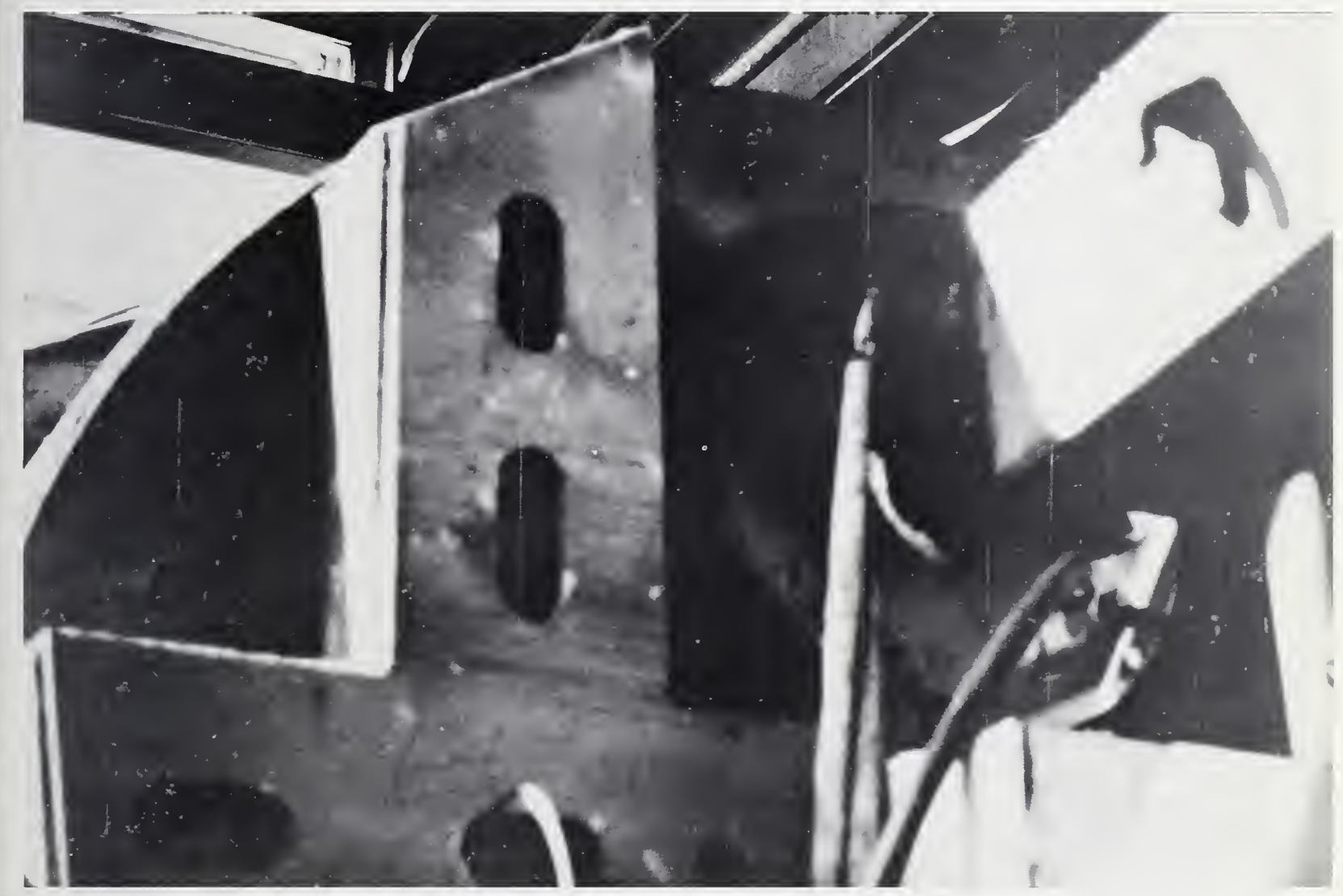

Figure 17. Photograph of "charging side" of furnace, showing launder (filling chute) present at opening in upper part of wall. 


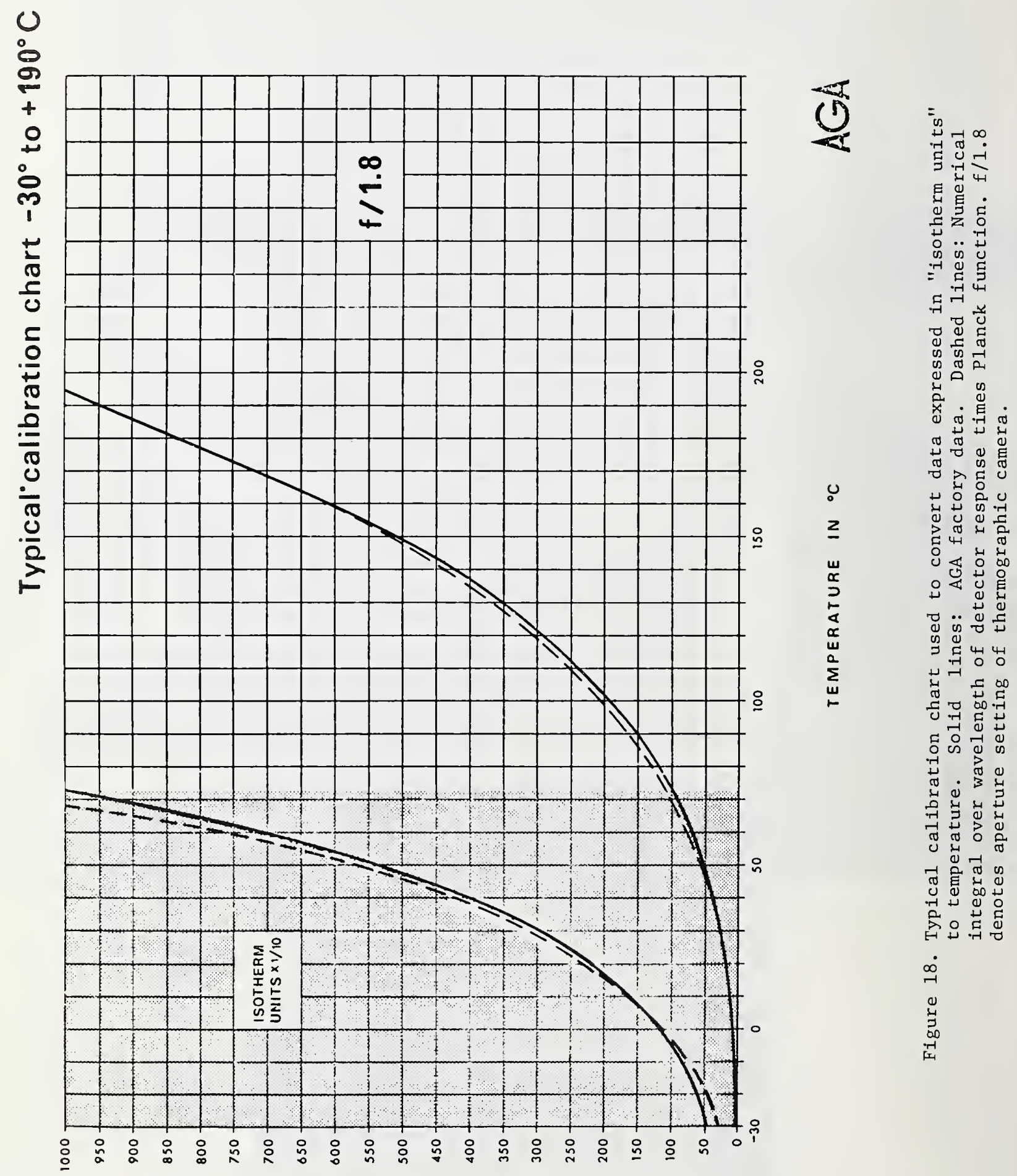




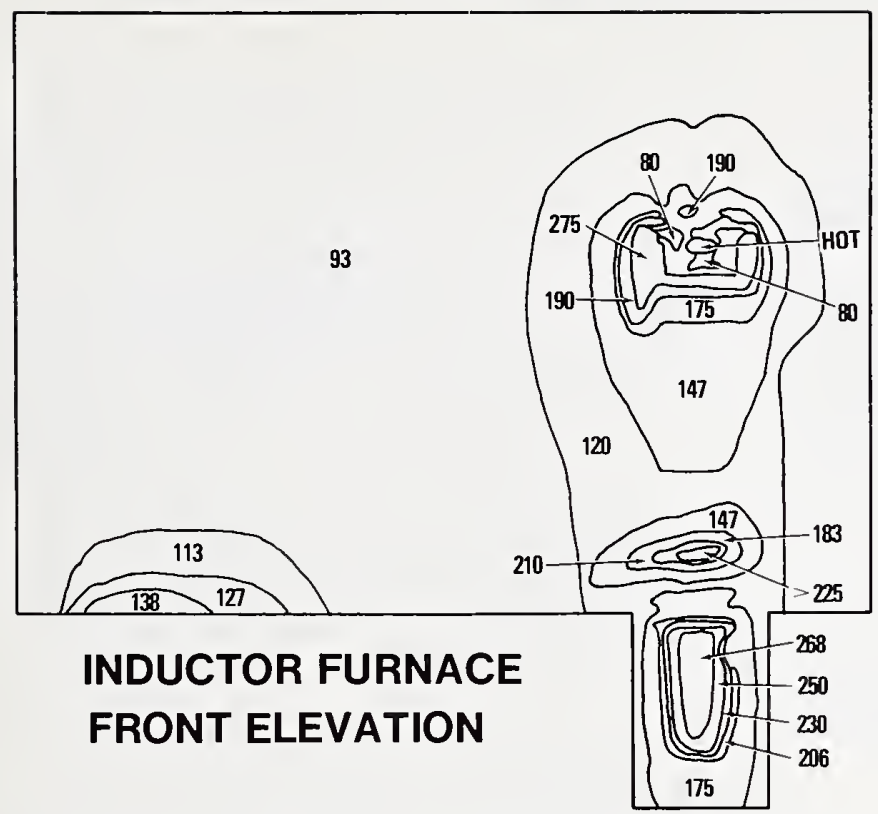

Figure 19. Temperature Map of Furnace Front.

\section{TEMPERATURE MAP $\left({ }^{\circ} \mathrm{C}\right)$}

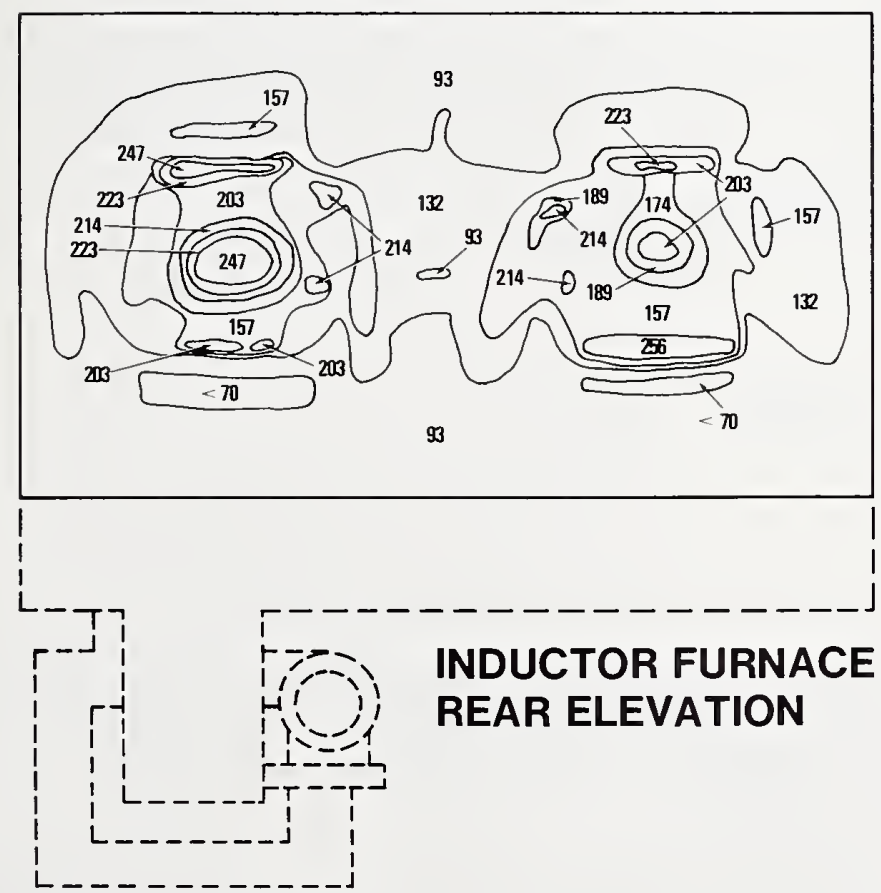

Figure 20. Temperature Map of Furnace Back. 


\section{EQUAL AREA PROJECTION MAP}

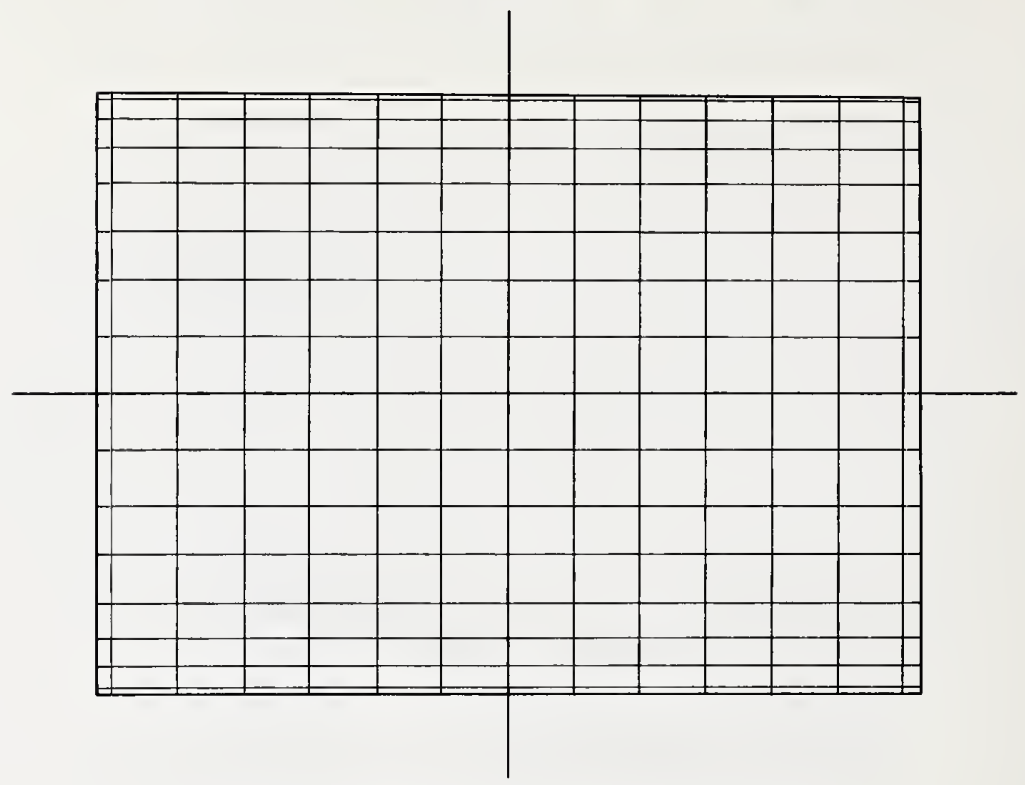

EACH RECTANGLE = 1 SQUARE FOOT

Figure 21. Equal-area chart used'in conjunction with temperature maps to determine areas contributing to total heat loss calculation. Each rectangle equals one square foot.

\section{HEAT BALANCE ON A CHANNEL INDUCTOR FURNACE}

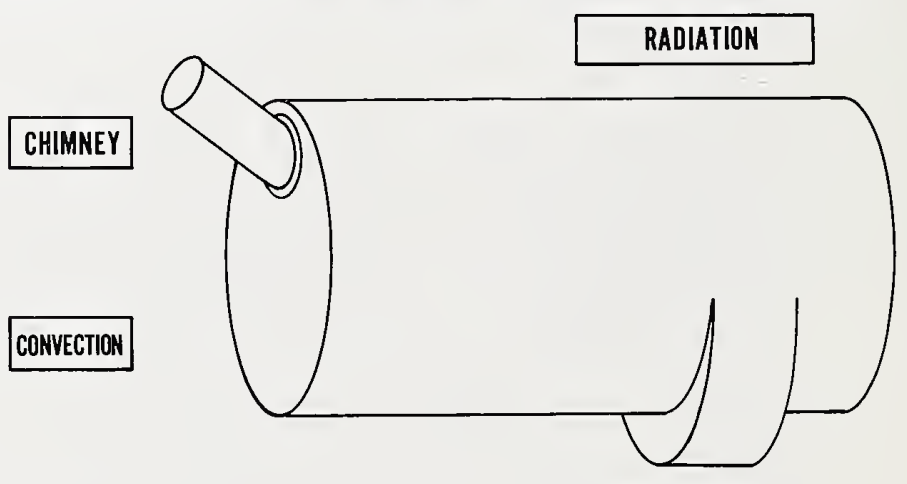

WATER JACKET

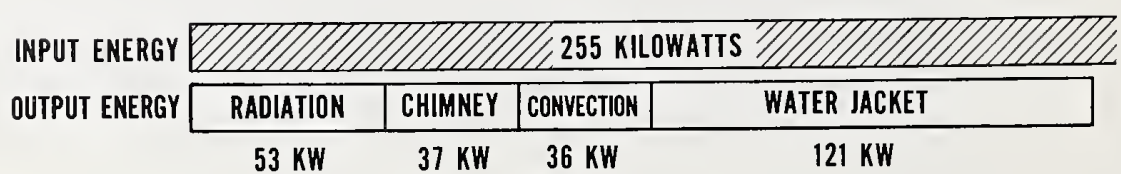

Figure 22. Sketch of furnace and bar chart to show cumulative heat loss by radiation, convection, conduction, and chimney effects. 


\begin{tabular}{|c|c|}
\hline $\begin{array}{c}\text { U.S. DEPT. OF COMM. } \\
\text { BIBLIOGRAPHIC DATA } \\
\text { SHEET }\end{array}$ & 1. PUBLICATION OR REPORT NO. \\
\hline
\end{tabular}

4. TITLE AND SUBTITLE

Use of Infrared Thermography for Industrial Heat Balance Calculations

\section{7. $\mathrm{AUTHOR}(\mathrm{S})$}

Kenneth G. Kreider and Thomas P. Sheahen
9. PERFORMING ORGANIZATION NAME AND ADDRESS

NATIONAL BUREAU OF STANDARDS

DEPARTMENT OF COMMERCE

WASHINGTON, DC 20234

12. SPONSORING ORGANIZATION NAME AND COMPLETE ADDRESS (Street, City, State, zIP)

Same as item 9 .

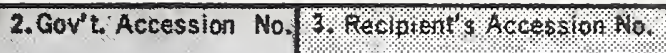

5. Publication Date

July 1980

6. Performing Organization Code

8. Performing Organ. Report No.

10. Prolect/Task/Nork Unit No.

11. Contract/Grant No.

13. Type of Report \& Period Covered

Final

14. Sponsoring Agency Code

\section{SUPPLEMENTARY NOTES}

Document describes a computer program; SF-185, FIPS Software Summary, is attached.

16. ABSTRACT (A 200-word or less factual summary of most significant information. If document includes a significant bibliography or Iiterature survey, mention it here.)

Infrared thermography has been used to estimate the radiant heat loss from a channel induction furnace containing molten iron. Using this infrared data, the surface temperature was mapped and the convective heat loss was calculated on the basis of a mixed forced and free-convection model. Additional calculations were performed to include the heat conducted away through a water jacket, and the heat lost by infiltration. The furnace energy input was $255 \mathrm{~kW}$, all electrical. The sum of radiation, convection, conduction, and infiltration losses was $246 \mathrm{~kW}$, but the water cooling alone had $\pm 30 \mathrm{~kW}$ associated with it. The radiative and convective losses $(89 \mathrm{~kW})$ were compared with the losses expected on the basis of the original design $(107 \mathrm{~kW})$, which is fair agreement. The value of infrared thermography for doing heat balances on industrial furnaces was assessed.

17. KEY WORDS (six to twelve entries; alphabetical order; capitalize only the first letter of the first key word unleas a proper name; separated by semicolons)

Heat balance; industrial furnaces; infrared; thermography。

18. AVAILABILITY

X Unlimited

For Official Distribution. Do Not Release to NTIS

X Order From Sup. of Doc., U.S. Government Printing Office, Washington, DC 20402 .

Order From National Technical Information Service (NTIS), Springfield, VA. 22161

\begin{tabular}{|l|c|}
\hline $\begin{array}{l}\text { 19. SECURITY CLASS } \\
\text { (THIS REPORT) } \\
\text { UNCLASSIFIED }\end{array}$ & $\begin{array}{c}\text { 21. NO. OF } \\
\text { PRINTED PAGES }\end{array}$ \\
\hline $\begin{array}{l}\text { 20. SECURITY CLASS } \\
\text { (THIS PAGE) } \\
\text { UNCLASSIFIED }\end{array}$ & \\
\hline
\end{tabular}





\section{NBS TECHNICAL PUBLICATIONS}

\section{PERIODICALS}

JOURNAL OF RESEARCH-The Journal of Research of the National Bureau of Standards reports NBS research and development in those disciplines of the physical and engineering sciences in which the Bureau is active. These include physics, chemistry, engineering, mathematics, and computer sciences. Papers cover a broad range of subjects, with major emphasis on measurement methodology and the basic technology underlying standardization. Also included from time to time are survey articles on topics closely related to the Bureau's technical and scientific programs. As a special service to subscribers each issue contains complete citations to all recent Bureau publications in both NBS and nonNBS media. Issued six times a year. Annual subscription: domestic \$13; foreign \$16.25. Single copy, \$3 domestic; \$3.75 foreign.

NOTE: The Journal was formerly published in two sections: Section A "Physics and Chemistry" and Section B "Mathematical Sciences."

DIMENSIONS/NBS-This monthly magazine is published to inform scientists, engineers, business and industry leaders, teachers, students, and consumers of the latest advances in science and technology, with primary emphasis on work at NBS. The magazine highlights and reviews such issues as energy research, fire protection, building technology, metric conversion, pollution abatement, health and safety, and consumer product performance. In addition, it reports the results of Bureau programs in measurement standards and techniques, properties of matter and materials, engineering standards and services, instrumentation, and automatic data processing. Annual subscription: domestic \$11; foreign $\$ 13.75$.

\section{NONPERIODICALS}

Monographs-Major contributions to the technical literature on various subjects related to the Bureau's scientific and technical activities.

Handbooks-Recommended codes of engineering and industrial practice (including safety codes) developed in cooperation with interested industries, professional organizations, and regulatory bodies.

Special Publications-Include proceedings of conferences sponsored by NBS, NBS annual reports, and other special publications appropriate to this grouping such as wall charts, pocket cards, and bibliographies

Applied Mathematics Series-Mathematical tables, manuals, and studies of special interest to physicists, engineers, chemists, biologists, mathematicians, computer programmers, and others engaged in scientific and technical work

National Standard Reference Data Series-Provides quantitative data on the physical and chemical properties of materials, compiled from the world's literature and critically evaluated. Developed under a worldwide program coordinated by NBS under the authority of the National Standard Data Act (Public Law 90-396)
NOTE: The principal publication outlet for the foregoing data is the Journal of Physical and Chemical Reference Data (JPCRD) published quarterly for NBS by the American Chemical Society (ACS) and the American Institute of Physics (AIP). Subscriptions, reprints, and supplements available from ACS, 1155 Sixteenth St., NW, Washington, DC 20056.

Building Science Series-Disseminates technical information developed at the Bureau on building materials, components, systems, and whole structures. The series presents research results, test methods, and performance criteria related to the structural and environmental functions and the durability and safety characteristics of building elements and systems.

Technical Notes-Studies or reports which are complete in themselves but restrictive in their treatment of a subject. Analogous to monographs but not so comprehensive in scope or definitive in treatment of the subject area. Often serve as a vehicle for final reports of work performed at NBS under the sponsorship of other government agencies.

Voluntary Product Standards-Developed under procedures published by the Department of Commerce in Part 10, Title 15, of the Code of Federal Regulations. The standards establish nationally recognized requirements for products, and provide all concerned interests with a basis for common understanding of the characteristics of the products. NBS administers this program as a supplement to the activities of the private sector standardizing organizations.

Consumer Information Series-Practical information, based on NBS research and experience, covering areas of interest to the consumer. Easily understandable language and illustrations provide useful background knowledge for shopping in today's technological marketplace.

Order the above NBS publications from: Superintendent of Documents, Government Printing Office, Washington, DC 20402.

Order the following NBS publications-FIPS and NBSIR's-from the National Technical Information Services, Springfield, VA 22161.

Federal Information Processing Standards Publications (FIPS PUB)-Publications in this series collectively constitute the Federal Information Processing Standards Register. The Register serves as the official source of information in the Federal Government regarding standards issued by NBS pursuant to the Federal Property and Administrative Services Act of 1949 as amended, Public Law 89-306 (79 Stat. 1127), and as implemented by Executive Order 11717 (38 FR 12315, dated May 11, 1973) and Part 6 of Title 15 CFR (Code of Federal Regulations).

NBS Interagency Reports (NBSIR) - A special series of interim or final reports on work performed by NBS for outside sponsors (both government and non-government). In general, initial distribution is handled by the sponsor; public distribution is by the National Technical Information Services, Springfield, VA 22161, in paper copy or microfiche form.

\section{BIBLIOGRAPHIC SUBSCRIPTION SERVICES}

The following current-awareness and literature-survey bibliographies are issued periodically by the Bureau:

Cryogenic Data Center Current Awareness Service. A literature survey issued biweekly. Annual subscription: domestic \$25; foreign $\$ 30$.

Liquefied Natural Gas. A literature survey issued quarterly. Annual subscription: $\$ 20$.
Superconducting Devices and Materials. A literature survey issued quarterly. Annual subscription: \$30. Please send subscription orders and remittances for the preceding bibliographic services to the National Bureau of Standards, Cryogenic Data Center (736) Boulder, CO 80303. 
U.S. DEPARTMENT OF COMMERCE

National Bureau of Standards

Washington, D.C. 20234

POSTAGE AND FEES PAID U.S. DEPARTMENT OF COMMERCE COM-215

OFFICIAL BUSINESS

Penalty for Private Use, $\$ 300$ 